\title{
\#USGS
}

science for a changing world

Prepared in cooperation with the National Park Service

Mercury and Water-Quality Data from Rink Creek, Salmon Creek, and Good River, Glacier Bay National Park and Preserve, Alaska, November 2009-October 2011

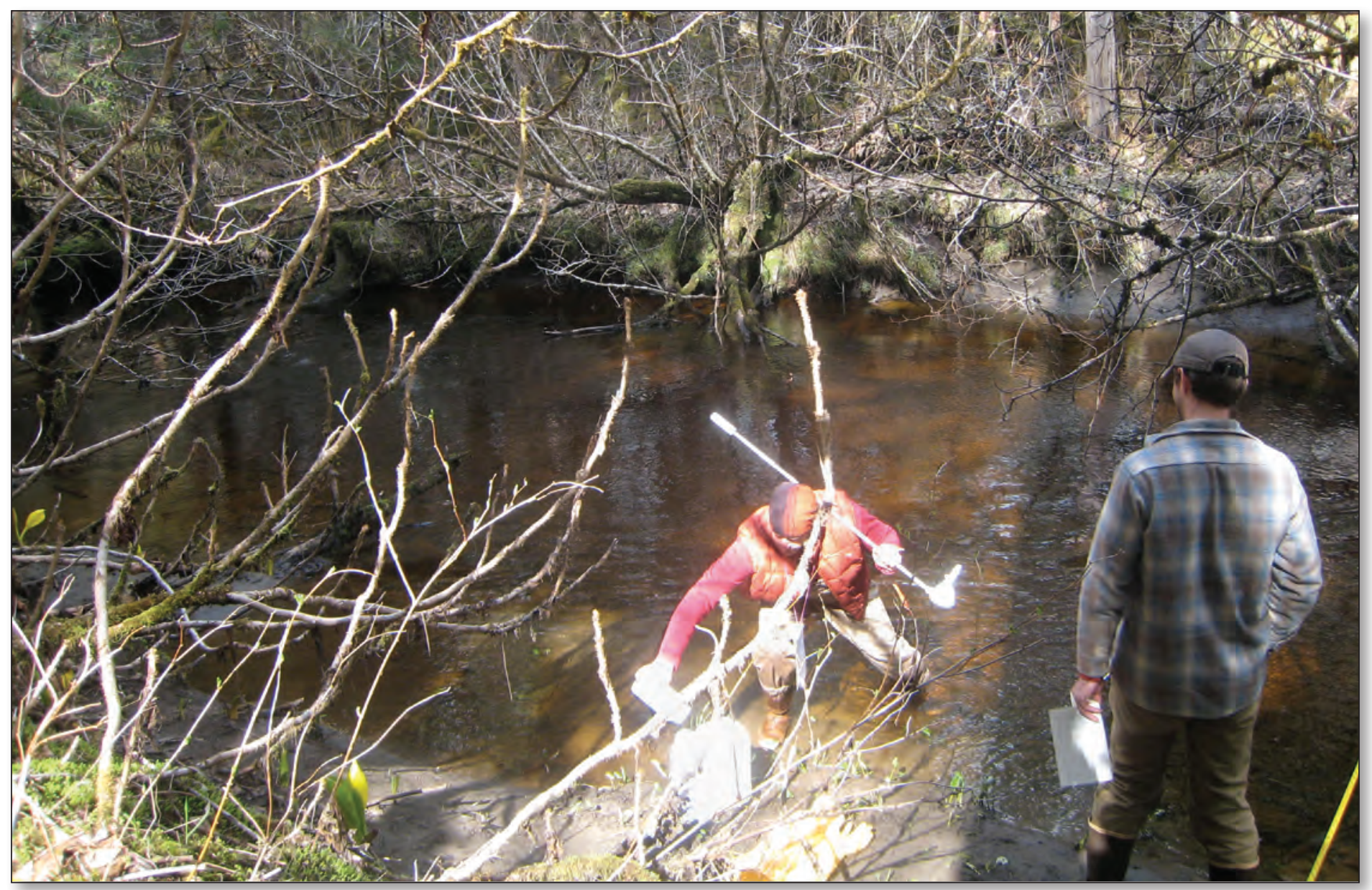

Open-File Report 2013-1097 
Cover: Water sampling at Rink Creek, Glacier Bay National Park and Preserve, Alaska. Photograph taken by Sonia A. Nagorski, University of Alaska

Southeast, April 22, 2010. 


\section{Mercury and Water-Quality Data from Rink Creek, Salmon River, and Good River, Glacier Bay National Park and Preserve, Alaska, November 2009-October 2011}

By Sonia A. Nagorski, Edward G. Neal, and Timothy P. Brabets

Prepared in cooperation with the National Park Service

Open-File Report 2013-1097 


\title{
U.S. Department of the Interior SALLY JEWELL, Secretary
}

\section{U.S. Geological Survey Suzette M. Kimball, Acting Director}

\author{
U.S. Geological Survey, Reston, Virginia: 2013
}

For more information on the USGS - the Federal source for science about the Earth, its natural and living resources, natural hazards, and the environment, visit http://www.usgs.gov or call 1-888-ASK-USGS.

For an overview of USGS information products, including maps, imagery, and publications, visit http://www.usgs.gov/pubprod

To order this and other USGS information products, visit http://store.usgs.gov

Any use of trade, firm, or product names is for descriptive purposes only and does not imply endorsement by the U.S. Government.

Although this information product, for the most part, is in the public domain, it also may contain copyrighted materials as noted in the text. Permission to reproduce copyrighted items must be secured from the copyright owner.

Suggested citation:

Nagorski, S.A., Neal, E.G., and Brabets, T.P., 2013, Mercury and water-quality data from Rink Creek, Salmon River, and Good River, Glacier Bay National Park and Preserve, Alaska, November 2009-October 2011: U.S Geological Survey Open-File Report 2013-1097, 20 p., http://pubs.usgs.gov/ofr/2013/1097. 


\section{Contents}

Abstract
Introduction
Purpose and Scope
Description of Study Area
Climate
Local Atmospheric Mercury Deposition
And Analytical Methods
Quality Assurance for Mercury Analyses
Analytical Methods for Other Water-Quality Parameters
Acknowledgments
References Cited

\section{Figures}

1. Maps showing locations of Glacier Bay National Park and Preserve, and aerial image of Rink Creek, Salmon River, and Good River watersheds and sampling sites,

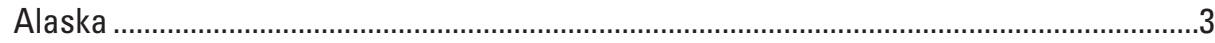

2. Maps showing wetland delineations within Rink Creek, Salmon River, and Good River watersheds, Glacier Bay National Park and Preserve, Alaska ................................5

3. Graph showing daily and long-term average precipitation for Gustavus, Alaska,

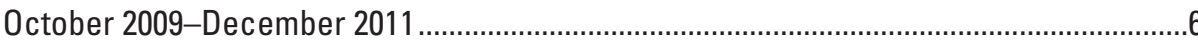

4. Graph showing daily maximum and minimum air temperature and long-term average daily maximum and minimum air temperature for Gustavus, Alaska, October 2009-December 2011.

\section{Tables}

1. Physical characteristics of Rink Creek, Salmon River, and Good River watersheds, Glacier Bay National Park and Preserve, Alaska..........................................................

2. Watershed areas and wetland coverage of Rink Creek, Salmon River, and Good River, Glacier Bay National Park and Preserve, Alaska...

3. Mercury concentration in wet deposition and mercury deposition from weekly samples collected at the Mercury Deposition Network collection site at Bartlett Cove, Alaska, March 24, 2010, to November 1, 2011

4. Discharge, $\mathrm{pH}$, dissolved oxygen, specific conductance, dissolved organic carbon, ultraviolet absorbance, and specific ultraviolet absorbance in water samples collected at Rink Creek, Salmon River, and Good River, Glacier Bay National Park and Preserve, Alaska, November 9, 2009, to October 26, 2011 


\section{Tables-Continued}

5. Filtered and particulate total mercury and methylmercury concentrations, and the percent of total mercury occurring in the filtered phase, in water samples collected at Rink Creek, Salmon River, and Good River, Glacier Bay National Park and Preserve, Alaska, November 9, 2009, to October 26, 2011

6. Instantaneous flux and specific flux for total mercury and methylmercury in the filtered and particulate phase, and dissolved organic carbon flux and specific flux for Rink Creek, Glacier Bay National Park and Preserve, Alaska, November 9, 2009, to October 26, 2011

7. Instantaneous flux and specific flux for total mercury and methylmercury in the filtered and particulate phase, and dissolved organic carbon flux and specific flux for Salmon River, Glacier Bay National Park and Preserve, Alaska, November 9, 2009, to October 26, 2011

8. Instantaneous flux and specific flux for total mercury and methylmercury in the filtered and particulate phase, and dissolved organic carbon flux and specific flux for Good River, Glacier Bay National Park and Preserve, Alaska, November 9, 2009, to October 26, 2011

9. Concentrations of total mercury in streambed sediments collected at Rink Creek, Salmon River, and Good River, Glacier Bay National Park and Preserve, Alaska, May 24, 2010

10. Taxonomy, trophic position, and mercury concentrations in benthic macroinvertebrates from Rink Creek, Salmon River, and Good River, Glacier Bay National Park and Preserve, Alaska, 2010 and 2011

11. Methylmercury and total mercury concentrations (wet weight and dry weight) in juvenile coho salmon samples from Rink Creek, Salmon River, and Good River, Glacier Bay National Park and Preserve, Alaska, 2010 and 2011

12. Concentrations of total dissolved solids, major anions, and major cations from water samples collected at Rink Creek, Salmon River, and Good River, Glacier Bay National Park and Preserve, Alaska, 2010

13. Concentrations of ammonia, nitrogen and phosphorus species, dissolved iron, and dissolved manganese from water samples collected at Rink Creek, Salmon River, and Good River, Glacier Bay National Park and Preserve, Alaska, 2010 


\title{
Conversion Factors, Datums, and Abbreviations and Acronyms
}

\author{
Conversion Factors
}

\begin{tabular}{lcl}
\hline \multicolumn{1}{c}{ Multiply } & By & \multicolumn{1}{c}{ To obtain } \\
\hline centimeter $(\mathrm{cm})$ & Length & \\
millimeter $(\mathrm{mm})$ & 0.3937 & inch (in.) \\
meter $(\mathrm{m})$ & 0.03937 & inch (in.) \\
kilometer $(\mathrm{km})$ & 3.281 & foot (ft) \\
& 0.6214 & mile (mi) \\
\hline square kilometer $\left(\mathrm{km}^{2}\right)$ & Area & acre \\
square kilometer $\left(\mathrm{km}^{2}\right)$ & 247.1 & square mile $\left(\mathrm{mi}^{2}\right)$ \\
\hline & 0.3861 & quart (qt) \\
\hline liter $(\mathrm{L})$ & Volume & gallon (gal) \\
liter $(\mathrm{L})$ & 1.057 & \\
\hline & 0.2642 & cubic foot per second $\left(\mathrm{ft}{ }^{3} / \mathrm{s}\right)$ \\
\hline
\end{tabular}

Temperature in degrees Celsius $\left({ }^{\circ} \mathrm{C}\right)$ may be converted to degrees Fahrenheit $\left({ }^{\circ} \mathrm{F}\right)$ as follows:

$$
{ }^{\circ} \mathrm{F}=\left(1.8 x^{\circ} \mathrm{C}\right)+32 \text {. }
$$

Concentrations of chemical constituents in water are given either in milligrams per liter ( $\mathrm{mg} / \mathrm{L}$ ) or micrograms per liter $(\mu \mathrm{g} / \mathrm{L})$.

\section{Datums}

Vertical coordinate information is referenced to the North American Vertical Datum of 1988 (NAVD 88).

Horizontal coordinate information is referenced to the North American Datum of 1983 (NAD 83).

Elevation, as used in this report, refers to distance above the vertical datum. 


\title{
Conversion Factors, Datums, and Abbreviations and Acronyms - Continued
}

\author{
Abbreviations and Acronyms \\ Certain measurements used in this report are given only in metric units: \\ $\mathrm{ng} / \mathrm{L} \quad$ nanogram per liter \\ $\mathrm{ng} / \mathrm{s} \quad$ nanogram per second \\ $\mathrm{ng} / \mathrm{s} / \mathrm{km}^{2} \quad$ nanograms per second per square kilometer \\ $\mathrm{ng} / \mathrm{g} \quad$ nanograms per gram \\ $\mathrm{L} / \mathrm{mg} \mathrm{C} * \mathrm{~m} \quad$ liters per milligram carbon times meter \\ GBNPP Glacier Bay National Park and Preserve \\ BMI benthic macroinvertebrates \\ BTHg biota total mercury \\ DOC dissolved organic carbon \\ $\mathrm{FMHg} \quad$ filtered methylmercury \\ FTHg filtered total mercury \\ $\mathrm{HCl} \quad$ hydrochloric acid \\ $\mathrm{Hg} \quad$ mercury \\ Hgt total mercury \\ $\mathrm{MeHg} \quad$ methylmercury \\ MDN Mercury Deposition Network \\ MRL Mercury Research Laboratory \\ NWIS National Water Information System \\ PTHg particulate total mercury \\ SUVA specific ultraviolet absorbance \\ USGS U.S. Geological Survey \\ UVA ultraviolet absorbance
}




\title{
Mercury and Water-Quality Data from Rink Creek, Salmon River, and Good River, Glacier Bay National Park and Preserve, Alaska, November 2009-0ctober 2011
}

\author{
By Sonia A. Nagorski', Edward G. Neal'2, and Timothy P. Brabets ${ }^{2}$
}

\section{Abstract}

Glacier Bay National Park and Preserve (GBNPP), Alaska, like many pristine high latitude areas, is exposed to atmospherically deposited contaminants such as mercury (Hg). Although the harmful effects of Hg are well established, information on this contaminant in southeast Alaska is scarce. Here, we assess the level of this contaminant in several aquatic components (water, sediments, and biological tissue) in three adjacent, small streams in GBNPP that drain contrasting landscapes but receive similar atmospheric inputs: Rink Creek, Salmon River, and Good River.

Twenty water samples were collected from 2009 to 2011 and processed and analyzed for total mercury and methylmercury (filtered and particulate), and dissolved organic carbon quantity and quality. Ancillary stream water parameters (discharge, $\mathrm{pH}$, dissolved oxygen, specific conductance, and temperature) were measured at the time of sampling. Major cations, anions, and nutrients were measured four times. In addition, total mercury was analyzed in streambed sediment in 2010 and in juvenile coho salmon and several taxa of benthic macroinvertebrates in the early summer of 2010 and 2011.

\section{Introduction}

Mercury (Hg) is a global pollutant, dispersed over broad scales by atmospheric mixing and reaching remote areas where it is neither used nor produced (Nriagu and Pacyna, 1988; Fitzgerald and others, 1998). It is carried to Alaska by long-range atmospheric pathways (Schroeder and Munthe,
1998), and, upon deposition, it may be methylated and biomagnified as it passes up trophic levels (Wiener and others, 2003).

Although Hg emissions in the United States have decreased in recent decades, global emissions continue to increase, particularly in Asia (Pacyna and others, 2010). Specifically, China has been increasing its coal combustion by 12 percent per year since 2000, accounting for 46 percent of the world's use (Bradsher and Barboza, 2006; U.S. Energy Information Administration, 2012). Models show that much of the Hg released as a by-product of this coal combustion is carried atmospherically to the northern Pacific Ocean and northwest coast of North America (Dastoor and Larocque, 2004; Sunderland and others, 2009). Currently (2012), anthropogenic mercury deposition to Alaska appears to be similar in magnitude to that in temperate latitudes although local sources are minimal and scarce (Fitzgerald and others, 2005).

Little is known about $\mathrm{Hg}$ contamination in southern Alaska, even though available evidence indicates that the region increasingly is accumulating this toxin from atmospheric deposition or from biovectors from distant sources (Engstrom and Swain, 1997; Day and others, 2006). A National Park Service contaminant survey conducted in the region in 2007 provided an initial evaluation of $\mathrm{Hg}$ distribution in water, sediment, macroinvertebrate, and juvenile coho salmon (Nagorski and others, 2011). This project determined that, streams draining older, wetland-rich landscapes generally had higher total Hg and methylmercury (MeHg) concentrations than young, glacier-fed or recently deglaciated streams. The 2007 survey was based on a singleevent sampling and, therefore, trends were not examined.

\footnotetext{
${ }^{1}$ University of Alaska Southeast

${ }^{2}$ U.S. Geological Survey
} 


\section{Purpose and Scope}

With this project, we aimed to evaluate the temporal dynamics of $\mathrm{Hg}$ in three adjacent streams draining different landscape types - peatland-rich, peatland-forest mixed, and forest or meadow only. The main objectives of this study are to (1) measure Hg concentrations in water, sediment, and biota of three streams in Glacier Bay National Park and Preserve (GBNPP), Alaska, and to assess differences in $\mathrm{Hg}$ and $\mathrm{MeHg}$ (if any) among the streams, (2) examine the extent of temporal variation in concentrations and fluxes of total $\mathrm{Hg}$ and $\mathrm{MeHg}$ in the streams over an annual time period, and (3) provide a detailed baseline dataset for three streams in GBNPP to which future contaminant monitoring efforts may be compared.

This report contains water-quality and climate data collected by the U.S. Geological Survey (USGS) and other agencies from November 2009 to October 2011 at three stream sites, one atmospheric deposition site, and one climate station in GBNPP. Because some of the data presently (2012) cannot be stored in the USGS National Water Information System (NWIS), this report provides a single source to disseminate data that might not otherwise be available to the public.

\section{Description of Study Area}

The three study watersheds are directly adjacent to one another and located along the southeastern border of GBNPP and the town of Gustavus (fig. 1A). The Good River and about 10 percent of the Salmon River lie within the Gustavus forelands, a broad, low-elevation and low-relief area about $14 \mathrm{~km}$ in width (fig. 1B). The forelands are bordered to the west by a northeast-trending terminal moraine, formed about 250 years ago at the culmination of glacial ice advance during the Little Ice Age (Connor and others, 2009). To the east, the Gustavus forelands are flanked by the northwest-trending Excursion Ridge, which has been free of ice cover for about 13,000 years and rises to an elevation of about 1,050 m. Excursion Ridge is composed of upper Silurian rocks of the Alexander terrane-mostly limestones and mudstones of the Tidal Formation - that are covered by thick peat deposits and contain little forest cover (Rossman, 1963). The Gustavus forelands are composed of about 1,000 years of glacial deposits (largely outwash sands and silts) that overlay uplifted shallow marine sediments (Streveler, 1996).

The headwaters of the Good River originate from the terminal moraine, and flow through a mixture of spruce forest, horsetail, and herbaceous wet meadow. The Salmon River, located between Good River and Rink Creek, collects flow from the peatland-rich Excursion Ridge through a major upper tributary, and from the spruce forest and wet meadow zones of the Gustavus forelands. Rink Creek collects most of its flow from Excursion Ridge. Rink Creek is a sandy-bottomed, organic-rich stream typical of many peatland drainages across southeastern Alaska. Peat accumulations in coastal southeastern Alaska commonly are greater than $1 \mathrm{~m}$ deep, and this likely is true for Excursion Ridge (Fellman and others, 2007).

Of the three streams, the Salmon River is the largest and is the best supporter of established anadromous fish runs, including coho (Oncorhynchus kisutch), chum (O. keta), and pink salmon (O. gorbuscha) as well as Dolly Varden (Salvelinus malma malma) and steelhead trout (O. mykiss) (Alaska Department of Fish and Game, 2005). The Good River supports coho and chum salmon, and Rink Creek hosts coho and pink salmon, cutthroat trout, and Dolly Varden. Stream sampling locations, stream lengths, and elevations are provided in table 1 .

The percentage of each watershed covered by wetlands varies from 19 percent to 59 percent according to delineations by the National Wetlands Inventory Classification (U.S. Fish and Wildlife, variously dated) (table 2, fig. 2). The wetlands in the Gustavus Forelands, which include all of the Good River wetlands and about 10 percent of the Salmon River wetlands, are much younger with thinner organic matter deposits compared with the thick peatland accumulations that blanket Excursion Ridge in the Rink Creek and Salmon River watersheds.

\section{Climate}

The study area has a wet, moderate marine climate owing to frequent weak high-pressure systems in the summer and the dominance of a strong Aleutian Low in the northern Gulf of Alaska in the autumn, winter, and spring. According to records dating back to 1950 from the National Weather Service climate station at Gustavus (National Oceanic Atmospheric Association, variously dated), January is the coldest month, with an average temperature of -4.0 degrees Celsius $\left({ }^{\circ} \mathrm{C}\right)$, and July is the warmest month, with an average temperature of $12.8^{\circ} \mathrm{C}$. Average annual temperature is $4.8^{\circ} \mathrm{C}$. Mean annual precipitation is $141 \mathrm{~cm}$, and average annual snowfall is $193 \mathrm{~cm}$. The area typically has intermittent snowpack near sea level and continuous snow cover at elevations above $300 \mathrm{~m}$ during winter and early spring. Figures 3 and $\underline{4}$ show the daily precipitation and air temperature maxima and minima in Gustavus during the period of sampling. 
A.

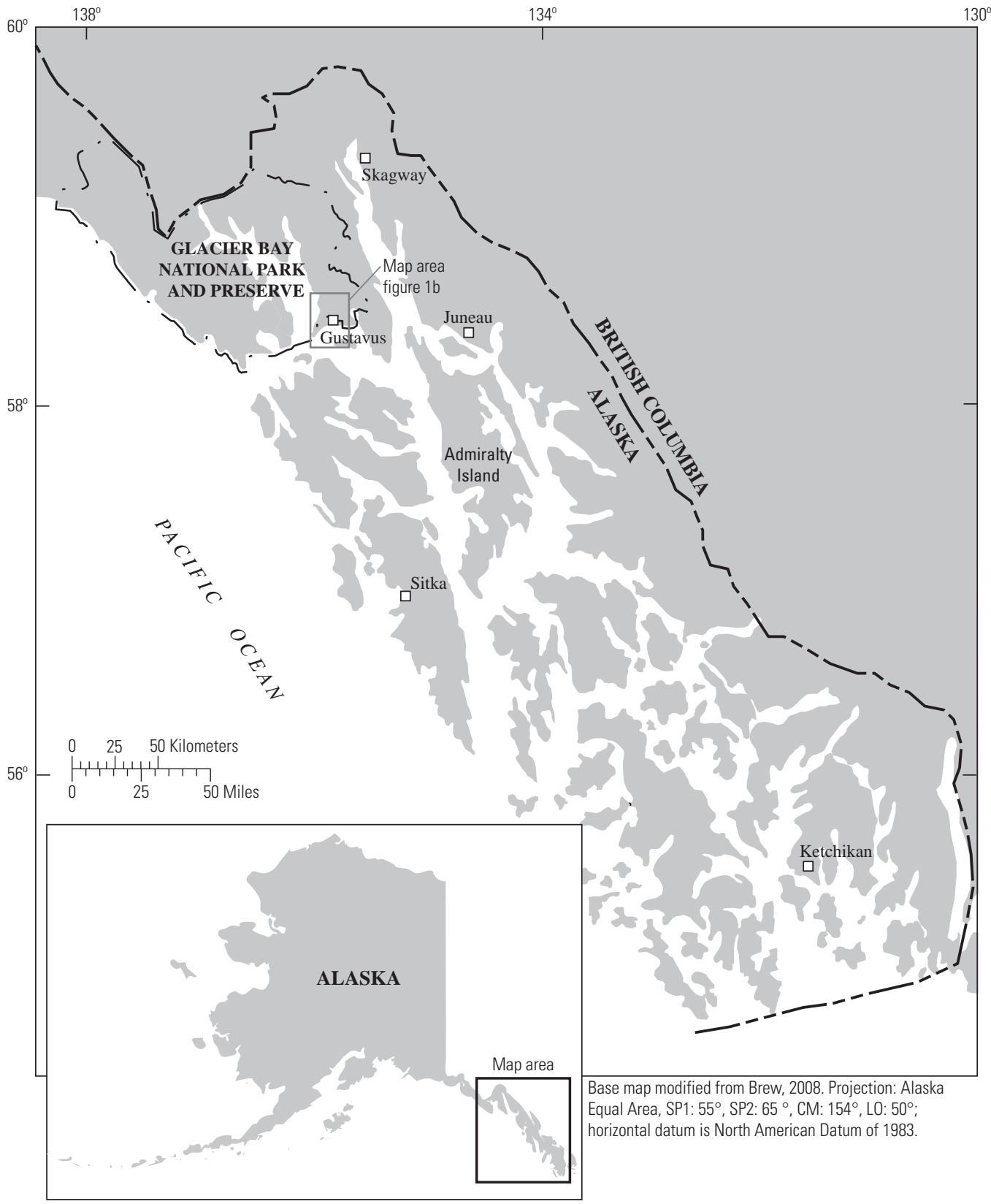

Figure 1. Locations of $(A)$ Glacier Bay National Park and Preserve, and $(B)$ aerial image of Rink Creek, Salmon River, and Good River watersheds and sampling sites, Alaska. 
B.

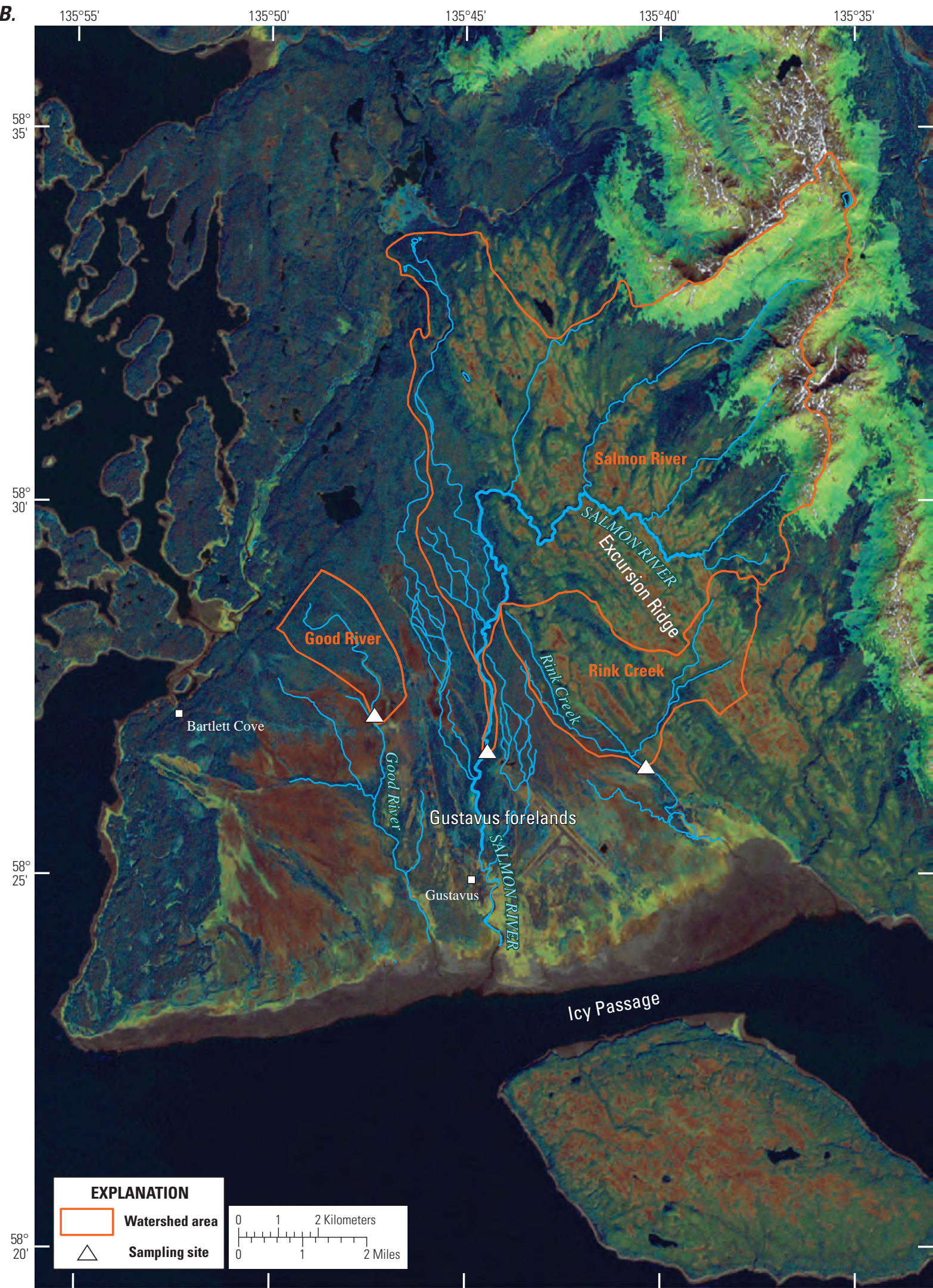

Landsat Thematic Mapper Image for Glacier Bay National Park and Preserve, accessed September 1, 2012, at https://irma.nps.gov/App/Reference/Profile/1040856.

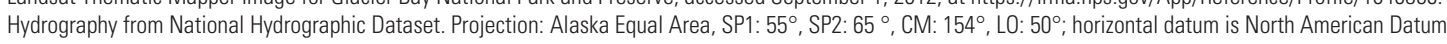

Figure 1.-Continued 

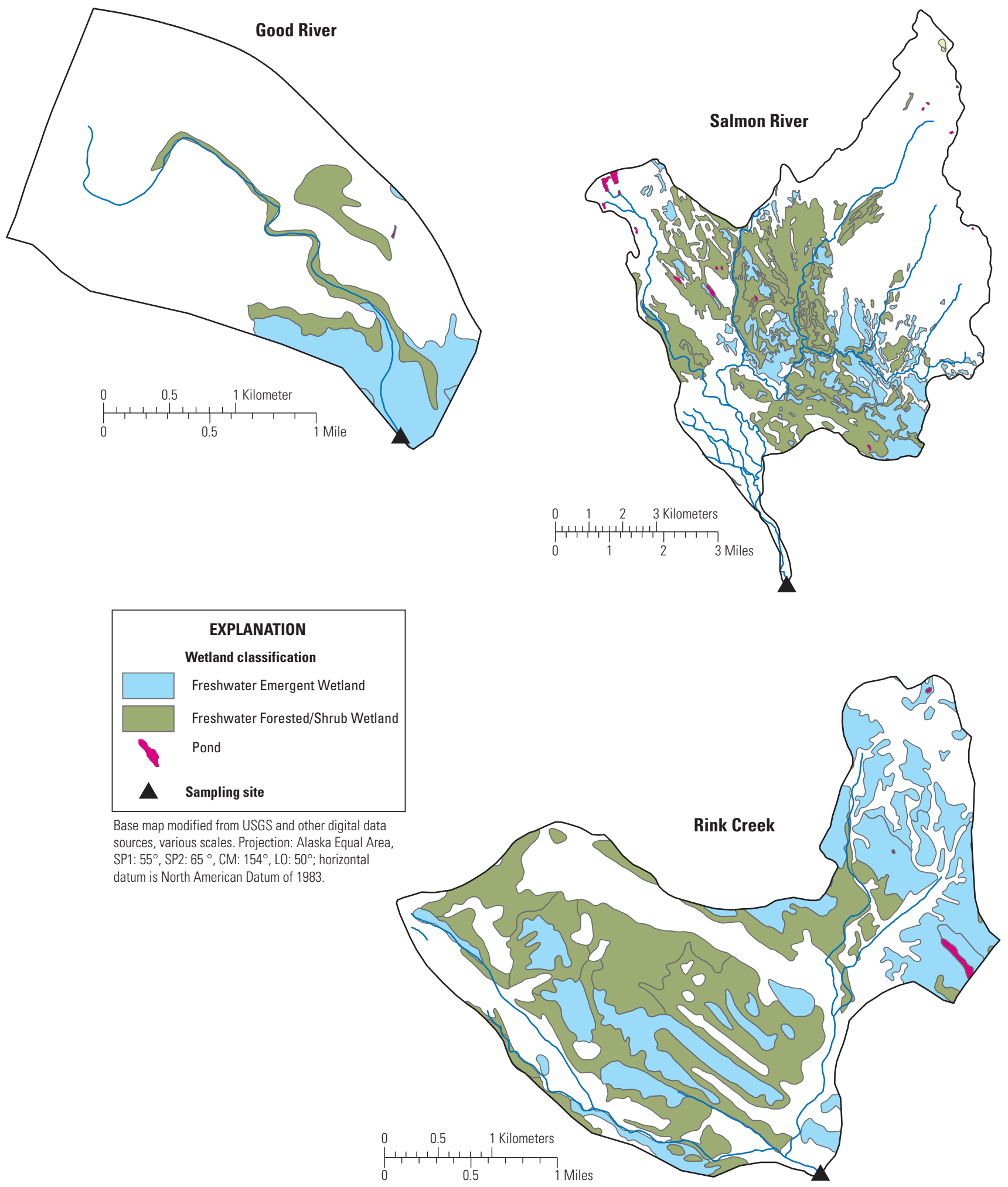

Figure 2. Wetland delineations within Rink Creek, Salmon River, and Good River watersheds, Glacier Bay National Park and Preserve, Alaska. (National Wetlands Inventory maps) 


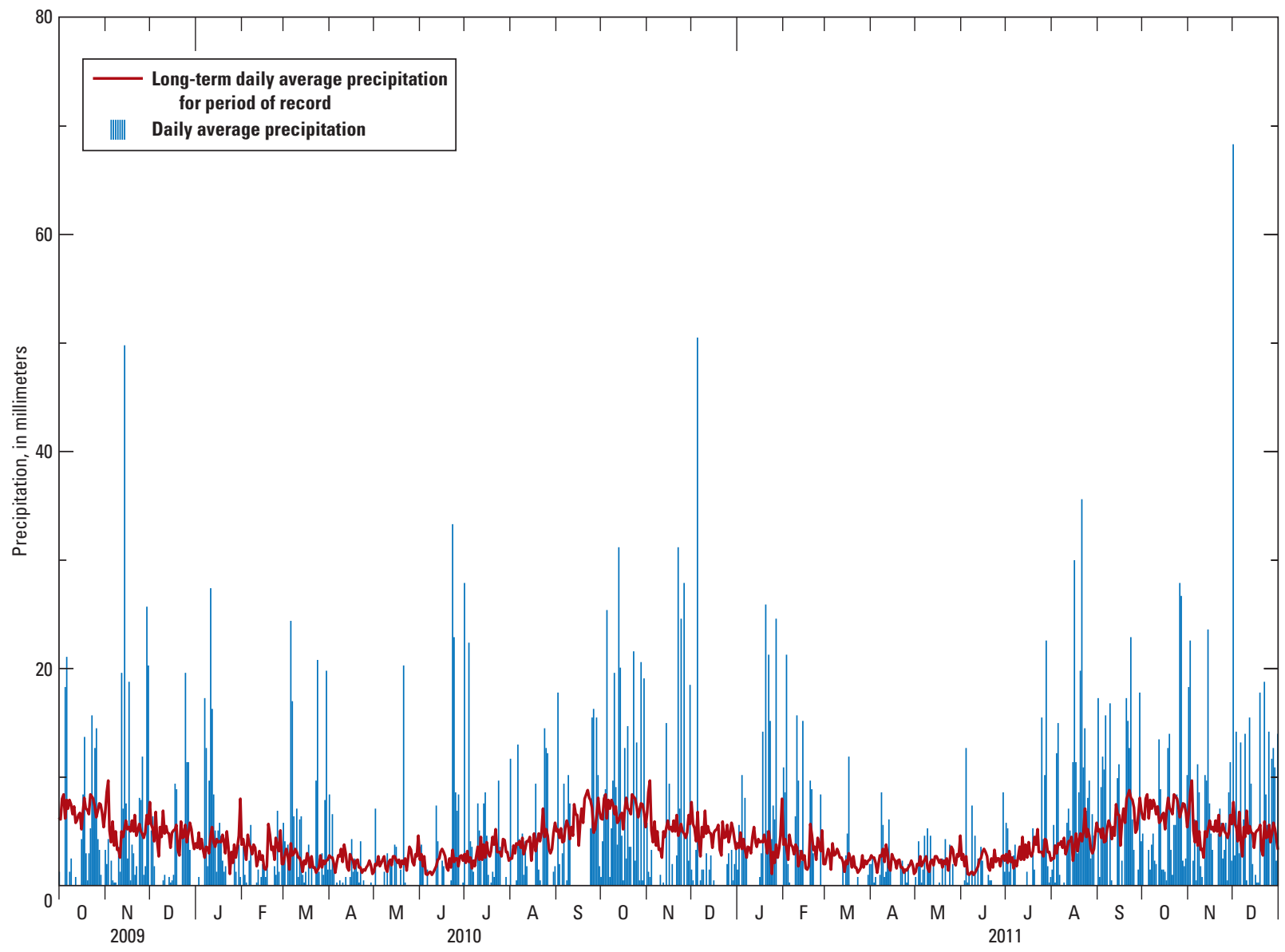

Figure 3. Daily and long-term average precipitation for Gustavus, Alaska, October 2009-December 2011.

Table 1. Physical characteristics of Rink Creek, Salmon River, and Good River watersheds, Glacier Bay National Park and Preserve, Alaska.

[Locations of sampling sites are shown in figure 1B. Abbreviations km, kilometer; m, meter; NAD 83, North American Datum of 1983]

\begin{tabular}{|c|c|c|c|c|c|c|}
\hline Site name & $\begin{array}{l}\text { USGS } \\
\text { site No. }\end{array}$ & $\begin{array}{l}\text { Latitude } \\
\text { (NAD 83) }\end{array}$ & $\begin{array}{l}\text { Longitude } \\
\text { (NAD 83) }\end{array}$ & $\begin{array}{c}\text { Stream } \\
\text { length }(\mathbf{k m})\end{array}$ & $\begin{array}{l}\text { Max watershed } \\
\text { elevation (m) }\end{array}$ & $\begin{array}{l}\text { Elevation at } \\
\text { site }(\mathrm{m})\end{array}$ \\
\hline Rink Creek & 15057593 & $58^{\circ} 26^{\prime} 32^{\prime \prime}$ & $135^{\circ} 40^{\prime} 24^{\prime \prime}$ & 4.9 & 450 & 27.4 \\
\hline Salmon River & 15057596 & $58^{\circ} 26^{\prime} 44^{\prime \prime}$ & $135^{\circ} 44^{\prime} 25^{\prime \prime}$ & 7.5 & 1,039 & 34.7 \\
\hline Good River & 15057598 & $58^{\circ} 27^{\prime} 02^{\prime \prime}$ & $135^{\circ} 47^{\prime} 17^{\prime \prime}$ & 4.7 & 58 & 16.8 \\
\hline
\end{tabular}

Table 2. Watershed areas and wetland coverage of Rink Creek, Salmon River, and Good River, Glacier Bay National Park and Preserve, Alaska.

[Locations of sampling sites are shown in figure $1 B$. Abloreviation: $\mathrm{km}^{2}$, square kilometer]

\begin{tabular}{lccccc}
\hline & & \multicolumn{3}{c}{ Freshwater $\left(\mathbf{k m}^{2}\right)$} & Wetland total \\
\cline { 3 - 6 } Site name & $\begin{array}{c}\text { Area } \\
\left(\mathbf{k m}^{2}\right)\end{array}$ & $\begin{array}{c}\text { Emergent } \\
\text { wetland }\end{array}$ & $\begin{array}{c}\text { Forested/ } \\
\text { shrub } \\
\text { wetland }\end{array}$ & Pond & $\begin{array}{c}\text { (percent of } \\
\text { total area) }\end{array}$ \\
\hline Rink Creek & 16.9 & 4.38 & 5.54 & 0.00 & 59 \\
Salmon River & 86.0 & 9.50 & 22.61 & 0.23 & 37 \\
Good River & 6.1 & 0.65 & 0.49 & 0.00 & 19 \\
\hline
\end{tabular}




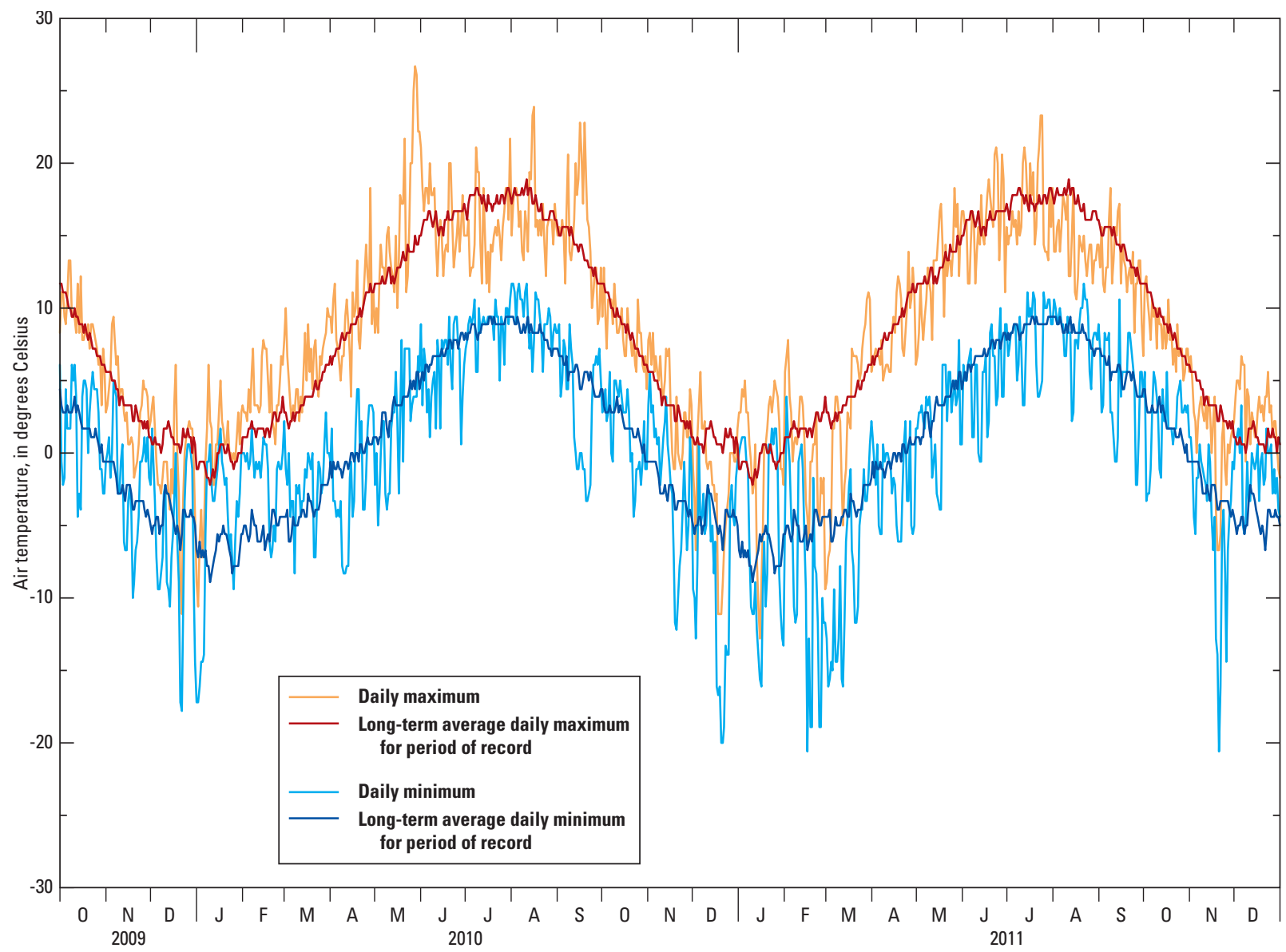

Figure 4. Daily maximum and minimum air temperature and long-term average daily maximum and minimum air temperature for Gustavus, Alaska, October 2009-December 2011.

\section{Local Atmospheric Mercury Deposition}

During much of the study period, the National Park Service operated a Mercury Deposition Network (MDN) site in nearby Bartlett Cove (Station AK05), located 3-18 km from the study watersheds. Weekly wet deposition samples were collected following MDN procedures (http://nadp.sws.uiuc. edu/MDN/MDNfield.aspx) and analyzed for total mercury beginning in late March, 2010 (with 6 weeks of missing data). Data from these samples are available through the National Atmospheric Deposition Program (2012) and are listed in table 3.
Our compilation of the data provided at Bartlett Cove indicates that a weekly average of 50 nanograms per square meter $\left(\mathrm{ng} / \mathrm{m}^{2}\right)$ of total $\mathrm{Hg}$ was deposited at the site when MDN collections overlapped with our study (March 2010-November 1, 2011). Mean Hg concentration was 2.94 nanograms per liter (ng/L) ( $n=77)$; however, volumeweighted concentrations were lower, with a mean of $1.56 \mathrm{ng} / \mathrm{L}$. 
Table 3. Mercury concentration in wet deposition and mercury deposition from weekly samples collected at the Mercury Deposition Network collection site at Bartlett Cove, Alaska, March 24, 2010, to November 1, 2011.

[Abbreviations: mm, millimeters; mL, milliliters; $\mathrm{ng} / \mathrm{L}$, nanograms per liter; $\mathrm{ng} / \mathrm{m}^{2}$, nanograms per square meter; - , missing data]

\begin{tabular}{|c|c|c|c|c|}
\hline Date and Time & $\begin{array}{l}\text { Precipitation } \\
\text { (mm) }\end{array}$ & $\begin{array}{l}\text { Sample } \\
\text { volume } \\
\text { (mL) }\end{array}$ & $\begin{array}{c}\text { Mercury } \\
\text { concentration } \\
\text { (ng/L) }\end{array}$ & $\begin{array}{c}\text { Mercury } \\
\text { deposition } \\
\left(\mathrm{ng} / \mathrm{m}^{2}\right)\end{array}$ \\
\hline 03-24-2010, 0230 & 44.5 & 418.1 & 0.95 & 42.2 \\
\hline 03-30-2010, 2030 & 25.7 & 277.7 & 1.03 & 26.4 \\
\hline 04-01-2010, 0230 & 1.3 & - & - & - \\
\hline 04-06-2010, 2325 & 11.9 & 123.0 & 3.02 & 36.1 \\
\hline 04-13-2010, 1757 & 6.1 & 49.4 & 2.46 & 15.0 \\
\hline 04-21-2010, 0230 & 30.0 & 331.0 & 1.83 & 54.9 \\
\hline 04-27-2010, 2110 & 8.1 & 83.3 & 6.66 & 54.1 \\
\hline 05-05-2010, 0225 & 4.8 & 37.0 & 3.33 & 16.1 \\
\hline 05-12-2010, 0010 & 1.5 & 12.8 & 10.75 & 16.4 \\
\hline 05-18-2010, 1815 & 12.5 & 133.5 & 3.93 & 48.9 \\
\hline 05-26-2010, 0005 & 2.3 & 10.8 & 15.04 & 34.4 \\
\hline 06-01-2010, 1835 & 5.8 & 63.1 & 8.60 & 50.2 \\
\hline 06-09-2010, 0200 & 6.1 & 75.6 & 3.15 & 19.2 \\
\hline 06-16-2010, 0105 & 5.6 & 70.2 & 7.20 & 40.2 \\
\hline 06-24-2010, 0440 & 68.6 & 796.3 & 1.27 & 87.1 \\
\hline 06-29-2010, 2245 & 14.5 & 164.4 & 1.36 & 19.7 \\
\hline 07-06-2010, 1925 & 53.9 & 620.7 & 1.72 & 92.6 \\
\hline 07-13-2010, 1950 & 22.9 & 236.6 & 5.45 & 124.6 \\
\hline 07-20-2010, 1820 & 12.7 & 141.6 & 3.44 & 43.7 \\
\hline 07-27-2010, 1837 & 21.3 & 259.3 & 1.89 & 40.3 \\
\hline 08-03-2010, 1750 & 9.7 & 109.2 & 2.28 & 22.0 \\
\hline 08-10-2010, 2105 & 24.1 & 263.6 & 2.13 & 51.4 \\
\hline 08-18-2010, 0120 & 5.1 & 52.7 & 4.83 & 24.5 \\
\hline 08-24-2010, 2345 & 36.6 & 432.5 & 1.29 & 47.2 \\
\hline 09-01-2010, 0210 & 25.9 & 269.7 & 2.54 & 65.8 \\
\hline 09-07-2010, 2320 & 47.8 & 537.4 & 0.87 & 41.5 \\
\hline 09-14-2010, 2050 & 9.9 & 125.6 & 2.71 & 26.9 \\
\hline 09-28-2010, 2140 & 79.5 & 878.2 & 0.78 & 62.0 \\
\hline 10-05-2010, 1825 & 84.8 & $1,035.7$ & 0.75 & 63.6 \\
\hline 10-13-2010, 0110 & 59.7 & 744.3 & 0.79 & 47.2 \\
\hline 10-19-2010, 1815 & 102.1 & $1,275.7$ & - & - \\
\hline 10-27-2010, 0100 & 6.6 & 58.0 & 0.85 & 5.6 \\
\hline 11-03-2010, 0210 & 69.3 & 826.0 & 0.76 & 52.7 \\
\hline 11-10-2010, 0105 & 72.9 & 839.0 & 1.86 & 135.6 \\
\hline 11-17-2010, 0140 & 63.3 & 716.9 & 0.81 & 51.2 \\
\hline 11-23-2010, 1855 & 0.0 & 0.0 & 0.00 & 0.0 \\
\hline $11-30-2010,2300$ & 59.9 & 697.9 & 1.10 & 65.9 \\
\hline $12-07-2010,2140$ & 66.6 & 536.0 & 0.87 & 57.9 \\
\hline $12-14-2010,2350$ & 12.2 & 128.7 & 1.31 & 16.0 \\
\hline 01-04-2011, 2000 & 47.8 & 481.2 & 1.03 & 49.2 \\
\hline
\end{tabular}


Table 3. Mercury concentration in wet deposition and mercury deposition from weekly samples collected at the Mercury Deposition Network collection site at Bartlett Cove, Alaska, March 24, 2010, to November 1, 2011.-Continued

[Abbreviations mm, millimeters; $\mathrm{mL}$, milliliters; $\mathrm{ng} / \mathrm{L}$, nanograms per liter; $\mathrm{ng} / \mathrm{m}^{2}$, nanograms per square meter; - , missing data]

\begin{tabular}{|c|c|c|c|c|}
\hline Date and Time & $\begin{array}{l}\text { Precipitation } \\
\quad(\mathrm{mm})\end{array}$ & $\begin{array}{l}\text { Sample } \\
\text { volume } \\
\text { (mL) }\end{array}$ & $\begin{array}{c}\text { Mercury } \\
\text { concentration } \\
\text { (ng/L) }\end{array}$ & $\begin{array}{c}\text { Mercury } \\
\text { deposition } \\
\left(\mathrm{ng} / \mathrm{m}^{2}\right)\end{array}$ \\
\hline 01-11-2011, 1900 & 16.0 & 177.9 & 0.91 & 14.6 \\
\hline 01-19-2011, 0050 & 16.3 & 56.9 & 3.16 & 51.4 \\
\hline 01-26-2011, 1745 & 112.8 & $1,167.4$ & 1.24 & 139.8 \\
\hline 02-08-2011, 1905 & 59.2 & 659.1 & 1.50 & 88.8 \\
\hline 02-15-2011, 2000 & 87.9 & 914.0 & 0.80 & 70.3 \\
\hline 03-01-2011, 1930 & 5.6 & 7.8 & 10.40 & 58.2 \\
\hline 03-17-2011, 2249 & 22.4 & 300.5 & 1.20 & 26.8 \\
\hline 03-29-2011, 1815 & 2.3 & 9.3 & 6.53 & 14.9 \\
\hline 04-05-2011, 2325 & 32.8 & 350.9 & 0.65 & 21.4 \\
\hline 04-12-2011, 2030 & 46.2 & 511.1 & 0.95 & 43.9 \\
\hline 04-20-2011, 0110 & 7.1 & 88.2 & 3.03 & 21.6 \\
\hline 04-26-2011, 2145 & 7.6 & 49.2 & 2.70 & 20.6 \\
\hline 05-04-2011, 0130 & 7.4 & 57.2 & 4.52 & 33.3 \\
\hline 05-11-2011, 0120 & 45.2 & 447.0 & 1.41 & 64.0 \\
\hline 05-18-2011, 0135 & 8.6 & 148.4 & 2.41 & 20.8 \\
\hline 05-24-2011, 1855 & 15.2 & 142.7 & 6.89 & 105.1 \\
\hline 06-01-2011, 0355 & 7.4 & 87.4 & 7.84 & 57.8 \\
\hline 06-07-2011, 2250 & 5.1 & 42.0 & 11.11 & 56.5 \\
\hline 06-14-2011, 1850 & 1.3 & 21.5 & 9.81 & 12.5 \\
\hline 06-22-2011, 0150 & 4.8 & 35.3 & 1.78 & 8.6 \\
\hline 06-29-2011, 0140 & 3.6 & 38.7 & 2.77 & 9.9 \\
\hline 07-06-2011, 0155 & 23.6 & 258.2 & 2.64 & 62.4 \\
\hline 07-13-2011, 0205 & 4.8 & 42.7 & 3.51 & 17.0 \\
\hline 07-20-2011, 0050 & 6.1 & 64.9 & 2.39 & 14.6 \\
\hline 07-26-2011, 2013 & 16.8 & 181.0 & 3.15 & 52.9 \\
\hline 08-02-2011, 2143 & 25.2 & 282.9 & 1.37 & 34.7 \\
\hline 08-09-2011, 2222 & 23.9 & 276.8 & 3.80 & 90.8 \\
\hline 08-17-2011, 0050 & 85.9 & $1,015.4$ & 1.06 & 91.0 \\
\hline 08-24-2011, 0135 & 110.2 & $1,373.9$ & 1.21 & 133.9 \\
\hline 08-30-2011, 2250 & 42.7 & 470.9 & 1.36 & 58.1 \\
\hline 09-07-2011, 0340 & 76.2 & 862.9 & 1.63 & 124.4 \\
\hline 09-13-2011, 1645 & 23.9 & 304.7 & 2.43 & 58.1 \\
\hline 09-20-2011, 2035 & 23.3 & 279.2 & 2.20 & 51.3 \\
\hline 09-27-2011, 1830 & 66.6 & 738.6 & 1.06 & 71.0 \\
\hline 10-04-2011, 2205 & 39.6 & 450.0 & 1.04 & 41.2 \\
\hline 10-11-2011, 1825 & 17.0 & 166.1 & 1.80 & 30.7 \\
\hline 10-18-2011, 2209 & 52.3 & 616.5 & 0.86 & 45.3 \\
\hline 10-25-2011, 2125 & 33.8 & 360.9 & 1.13 & 38.4 \\
\hline 11-01-2011, 2040 & 115.3 & $1,365.2$ & 0.75 & 87.2 \\
\hline
\end{tabular}




\section{Field and Analytical Methods}

Grab samples of water were collected at the same location at each stream 20 times between November 2009 and October 2011. Collection dates primarily were dictated by favorable weather conditions for flight access to the sites from Juneau, although generally we targeted one monthly sample during the first year and maximum hydrologic variability during the second year.

$\mathrm{Hg}$ and $\mathrm{MeHg}$ exposure in stream biota were assessed by collecting benthic macroinvertebrates (BMI) and resident fish. As primary consumers, BMI represent one of the lowest trophic levels for pollutants to enter into and biomagnify within aquatic food webs. Juvenile coho salmon that likely had not yet migrated out of their natal streams were targeted, with the aim of identifying a watershed-specific $\mathrm{Hg}$ signal in their tissues. Single streambed sediment samples also were collected at each stream site once in May 2010. Because streambed sediments, BMI, and fish are present together in small areas for extended periods of time, they integrate pollutants that may not be detected during standard water sampling, either because the pollutant is not present at detectable levels or is present intermittently (Krabbenhoft and others, 1999).

Water samples were collected by wading in the streams and using the best visual approximation of depth- and width-integrated conditions. Mercury water samples were collected in triple-rinsed, 2-L polyethylene terephthalate bottles, positioning the bottle upstream. The samples were then stored on ice, followed by clean filtration (through about 0.7 microgram [mm] ashed quartz fiber filters) and acidification ( 0.2 percent of sample volume) with ultraclean hydrochloric acid ( $\mathrm{HCl})$. Filtration was done the same day using a portable, metal-free filter apparatus. All pre-cleaned filtration equipment was provided by the USGS Mercury Research Laboratory (MRL) in Madison, Wisconsin. Particulate Hg was measured by analysis of filters through which $1 \mathrm{~L}$ of sample was passed. Additional water samples were filtered into amber glass bottles for dissolved organic carbon (DOC) analysis. Collection and processing procedures of samples for nutrients and major cations and anions followed USGS National Field Manual protocols (U.S. Geological Survey, variously dated).

Streambed sediment was collected by scraping several grams of the approximate top $1 \mathrm{~cm}$ of fine, unsieved sediment into a Teflon ${ }^{\circledR}$ vial. Mayfly nymphs or instars were dislodged from the streambed by foot and collected in a net. As many as 100 nymphs or instars from each family and stream were picked into a Teflon ${ }^{\circledR}$ vial. Seven to 10 juvenile coho salmon were captured at each site with a hand net or in baited minnow traps, and also were stored in small Teflon ${ }^{\circledR}$ vials. All samples were double-bagged, stored on ice, and handled by personnel wearing clean nitrile gloves. Sediment and biological specimens were frozen within 2 days. The age of the juvenile coho salmon - likely either 1 or 2 years old —-was not determined, although lengths were recorded; they were not young-of-the-year (fry), but, instead, were parr or smolts.

A Yellow Springs Instrument model 6920 multiparameter sonde ${ }^{\mathrm{TM}}$ was used to measure water temperature, dissolved-oxygen concentration, specific conductance, turbidity, and $\mathrm{pH}$ at the time of sampling. The sonde was calibrated using known standards before sample collection. Discharge measurements, using a wading rod and Price current meter, also were made at the time of sampling following methods outlined by Turnipseed and Sauer (2010).

\section{Analytical Methods for Mercury}

All $\mathrm{Hg}$ analyses were done at the USGS MRL. Aqueous total $\mathrm{Hg}\left(\mathrm{Hg}_{\mathrm{T}}\right)$ analysis followed U.S. Environmental Protection Agency (USEPA) Method 1631 (U.S. Environmental Protection Agency, 2002). Aqueous MeHg analyses were performed following standard distillation and ethylation procedures described in detail elsewhere (Horvat and Bloom, 1993; DeWild and others, 2001), followed by analysis by cold-vapor atomic fluorescence spectrometry. Particulate, sediment, and biological tissue samples were analyzed for $\mathrm{Hg}_{\mathrm{T}}$ and $\mathrm{MeHg}$ using the procedures described above; however, for each of these solid-phase samples, a solubilization step was first conducted to transform the sample into an aqueous state. For $\mathrm{Hg}_{\mathrm{T}}$ in sediments and particulates, about $100 \mathrm{mg}$ of homogenized, dried sample was digested in aqua regia (a mixture of nitric acid and hydrochloric acid) (Olund and others, 2004), whereas $\mathrm{MeHg}$ in sediment and particulates were solubilized with methylene chloride and heat (DeWild and others, 2004). Fish tissues and benthic invertebrates were digested in Teflon ${ }^{\circledR}$ bombs (a teflon container fitted in a steel jacket) using a concentrated mixture of nitric and sulfuric acids (5:2 volume-to-volume ratio) and were placed in an oven at $75^{\circ} \mathrm{C}$ for 2 hours. For $\mathrm{MeHg}$ solubilization of benthic invertebrates, a weak nitric acid method was used that included heating to $60^{\circ} \mathrm{C}$ in an oven and subsequent neutralization with potassium hydroxide (Hammerschmidt and Fitzgerald, 2006).

\section{Quality Assurance for Mercury Analyses}

Reference materials for $\mathrm{Hg}_{\mathrm{T}}$ were within 97-103 percent (mean=100 percent, $n=3$ ) of the reported values for fish analyses, $85-115$ percent (mean $=93$ percent, $\mathrm{n}=11$ ) for macroinvertebrate analyses, $66-120$ percent (mean=94 percent, $\mathrm{n}=35$ ) for particulates, and 100112 percent (mean=104 percent, $n=5$ ) for sediments. For $\mathrm{MeHg}$, reference materials were recovered at 84-109 percent (mean=94 percent, $\mathrm{n}=9$ ) for macroinvertebrates and 71-122 percent (mean=99 percent, $\mathrm{n}=15$ ) for particulates. 
The percent relative standard deviation of triplicate sample analyses of $\mathrm{Hg}_{\mathrm{T}}$ and $\mathrm{MeHg}$ in biological tissues averaged 6.0 percent and 5.9 percent ( $n=6$ for each), respectively, and 2.9 percent for triplicate runs of $\mathrm{Hg}_{\mathrm{T}}$ in sediment. Each water sample was run in duplicate for $\mathrm{Hg}_{\mathrm{T}}$, and the average difference between runs was 0.6 percent $(\mathrm{n}=64)$. Spike recoveries on filtered $\mathrm{Hg}_{\mathrm{T}}$ averaged 99.7 percent $(n=47)$ and 103 percent $(n=47)$ on filtered MeHg.

One field filtration blank was collected that was less than the detection limit for all mercury parameters: filtered total and $\mathrm{MeHg}$, as well as particulate total and $\mathrm{MeHg}$. In one sample (Salmon River, May 14, 2010), the filtered methylmercury (FMHg) value was greater than the filtered total mercury (FTHg) value; this sample was discarded from the dataset.

The mercury detection limit was between 1-2 nanograms per gram (ng/g) for benthic macroinvertebrates; 0.4-3.4 ng/g for fish samples; $0.02-0.1 \mathrm{ng} / \mathrm{L}$ for particulate $\mathrm{Hg}_{\mathrm{T}} ; 0.006 \mathrm{ng} / \mathrm{L}$ for particulate MeHg; $0.8 \mathrm{ng} / \mathrm{g}$ for sediment $\mathrm{Hg}_{\mathrm{T}}$; and between 0.02-0.04 ng/L for filtered $\mathrm{Hg}_{\mathrm{T}}$ and $\mathrm{MeHg}$.

Field duplicates of water samples were collected four times over the 2-year sampling period. The average discrepancy between the samples was $0.06 \mathrm{ng} / \mathrm{L}$ for filtered $\mathrm{Hg}_{\mathrm{T}} ; 0.01 \mathrm{ng} / \mathrm{L}$ for filtered $\mathrm{MeHg} ; 0.27 / \mathrm{ng} \mathrm{L}$ for particulate $\mathrm{Hg}_{\mathrm{T}}$; and $0.002 \mathrm{ng} / \mathrm{L}$ for particulate $\mathrm{MeHg}$. A field duplicate of juvenile coho samples was collected from the Salmon River during the 2011 collection, and variation between samples was 5 percent for $\mathrm{Hg}_{\mathrm{T}}$ and 8 percent for $\mathrm{MeHg}$.

\section{Analytical Methods for Other Water-Quality Parameters}

DOC was measured within 2 days of receipt using the platinum catalyzed persulphate wet oxidation method (Aiken, 1992) on an O.I. Analytical Model 700 TOC Analyzer at the USGS National Research Program laboratory in Boulder, Colorado. Ultraviolet (UV)-Visible absorbance measurements were made on a Hewlett-Packard Model $8453^{\mathrm{TM}}$ photo-diode array spectrophotometer every 1 nanometer (nm) between 200 and $800 \mathrm{~nm}$. Specific ultraviolet absorbance (SUVA) values (Weishaar and others, 2003), defined as the UV absorbance of the sample measured at a given wavelength divided by the DOC concentration, were calculated at $254 \mathrm{~nm}$ and are reported in units of liters per milligrams carbon times meter $([\mathrm{L} /(\mathrm{mg} \mathrm{C} * \mathrm{~m})])$ by normalizing to a $1-\mathrm{m}$ path length. Ultraviolet analyses were completed within 2 weeks of collection. Major ions and nutrients were analyzed at the USGS National Water Quality Laboratory in Denver, Colorado, using standard techniques (Fishman and Friedman, 1989).

\section{Mercury and Water-Quality Data}

The data have been compiled and are provided in tables 4-13. Field parameters collected at the time of sampling (discharge, $\mathrm{pH}$, dissolved oxygen, and specific conductance), DOC, ultraviolet absorbance (UVA), and SUVA values are given in table 4. Filtered and particulate $\mathrm{Hg}_{\mathrm{T}}$ and $\mathrm{MeHg}$ concentrations for the water samples are given in table 5 . Note that concentrations for filtered methymercury (FMHg) and particulate methylmercury (PMHg) in a number of samples were less than the detection limit.

The instantaneous and specific fluxes for $\mathrm{Hg}_{\mathrm{T}}$ and $\mathrm{MeHg}$ (filtered and particulate), and for DOC for each site are given in tables 6-8. Note that flux calculations were made only for samples with detectable mercury concentrations.

Concentrations of bed sediment, collected once on

May 14, 2010, and analyzed for $\mathrm{Hg}_{\mathrm{T}}$, are given in table 9. The results of benthic macroinvertebrate sampling in 2010 and 2011 are shown in table 10. In 2010, the macroinvertebrates were analyzed only for MeHg, but in 2011, they were analyzed for $\mathrm{MeHg}$ and $\mathrm{Hg}_{\mathrm{T}}$. In 2010, two genera were collected: a caddisfly (Onocosmoecus, Limnephilidae) and a mayfly (Baetis bicaudatus and B. tricaudatus, Baetidae). In June 2011, the same two taxa were collected in the study streams, except Baetis tricaudatus was not found in Good River. Three additional mayfly taxa were collected in Rink Creek and Salmon River for Hg analyses: Cinygmula, Ameletus, and Drunella grandis (Ephemerellidae). The mayfly Epeorus grandis (Heptageniidae) was collected only in Salmon River in 2011 and was combined with the Cinygmula (Heptageniidae) sample.

The results of juvenile coho salmon sampling in 2010 and 2011 are shown in table 11. In 2010, samples were analyzed only for $\mathrm{Hg}_{\mathrm{T}}$, but in 2011, the samples were analyzed for $\mathrm{MeHg}$ and $\mathrm{Hg}_{\mathrm{T}}$. Note that the samples were of non-uniform length, and that the ages of fish were undetermined (length alone does not determine age and, therefore, does not determine mercury exposure).

Concentrations of major anions, cations, and nutrients were measured four times in 2010 to obtain background waterquality information on Rink Creek, Salmon River, and Good River. Results are provided in tables 12 and $\underline{13}$. 


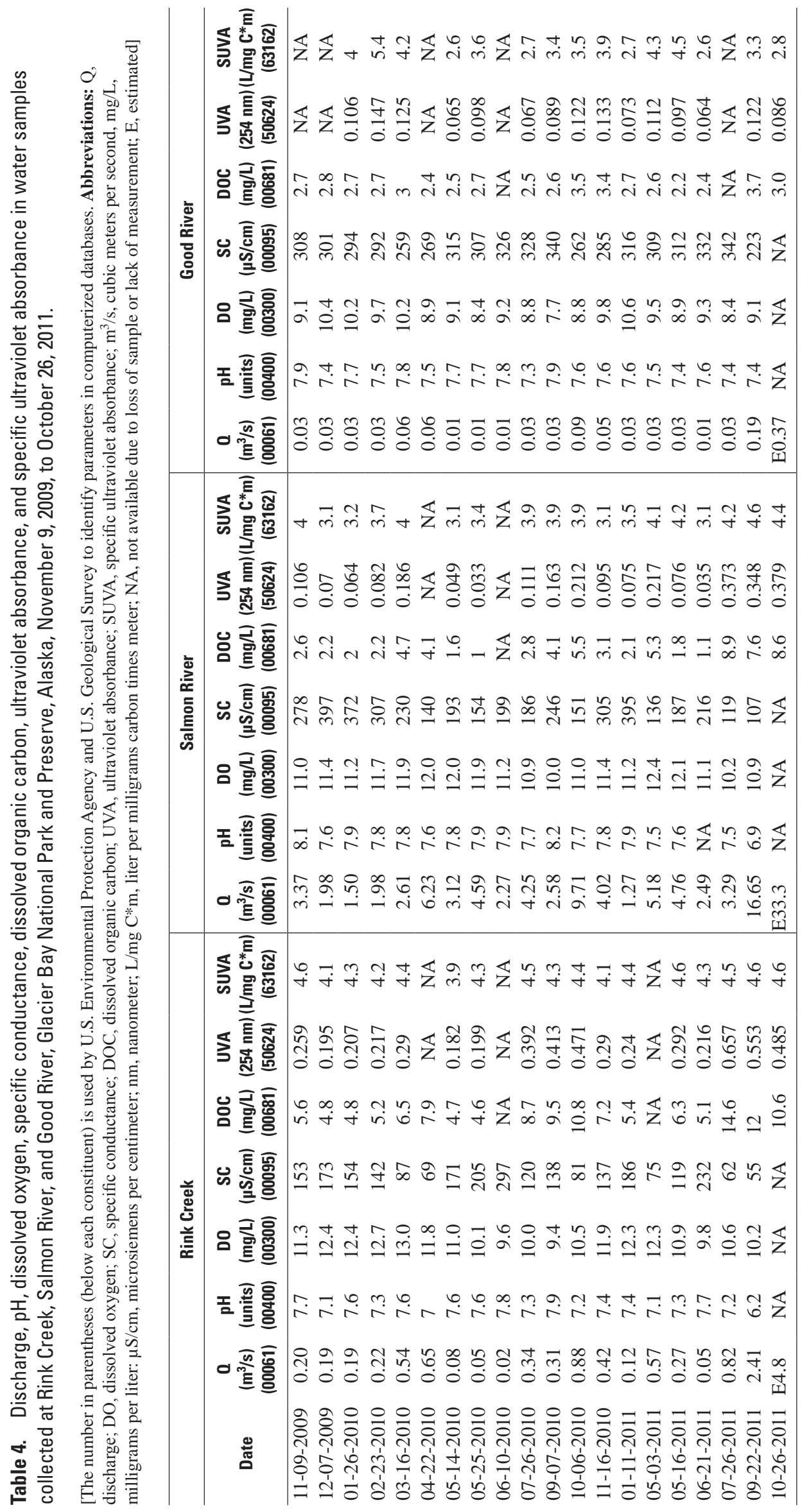




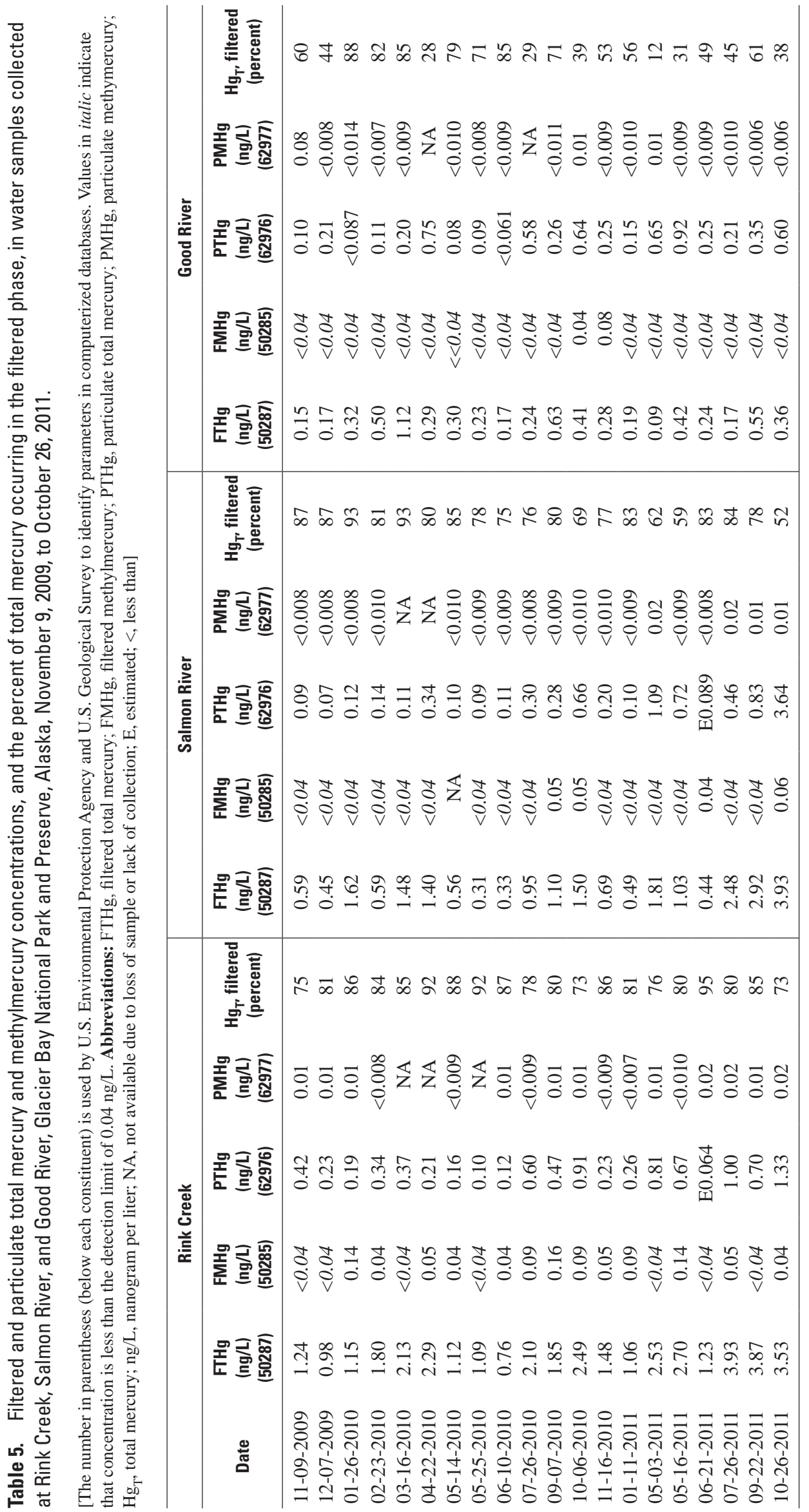


Table 6. Instantaneous flux and specific flux for total mercury and methylmercury in the filtered and particulate phase, and dissolved organic carbon flux and specific flux for Rink Creek, Glacier Bay National Park and Preserve, Alaska, November 9, 2009, to 0ctober 26, 2011.

[Abbreviations FTHg, filtered total mercury; FMHg, filtered methylmercury; PTHg, particulate total mercury; PMHg, particulate methylmercury; sp flux, specific flux; ng/s, nanograms per second; (ng/s)/km², nanograms per second per square kilometer; BDL, below detection limit; NA, not available due to loss of sample or lack of collection; E, estimated]

\begin{tabular}{|c|c|c|c|c|c|c|c|c|c|c|}
\hline Date & $\begin{array}{l}\text { FTHg flux } \\
\text { (ng/s) }\end{array}$ & $\begin{array}{l}\text { FTHg sp flux } \\
{\left[(\mathbf{n g} / \mathbf{s}) / \mathbf{k m}^{2}\right]}\end{array}$ & $\begin{array}{c}\text { FMHg flux } \\
\text { (ng/s) }\end{array}$ & $\begin{array}{c}\text { FMHg sp flux } \\
{\left[(\mathbf{n g} / \mathbf{s}) / \mathbf{k m}^{2}\right]}\end{array}$ & $\begin{array}{l}\text { PTHg flux } \\
\text { (ng/s) }\end{array}$ & $\begin{array}{l}\text { PTHg sp flux } \\
{\left[(\mathbf{n g} / \mathbf{s}) / \mathbf{k m}^{2}\right]}\end{array}$ & $\begin{array}{c}\text { PMHg flux } \\
\text { (ng/s) }\end{array}$ & $\begin{array}{l}\text { PMHg sp flux } \\
{\left[(\mathbf{n g} / \mathbf{s}) / \mathbf{k m}^{2}\right]}\end{array}$ & $\begin{array}{c}\text { DOC flux } \\
\text { (ng/s) }\end{array}$ & $\begin{array}{c}\text { DOC sp flux } \\
\left(\mathrm{ng} / \mathbf{s} / \mathbf{k m}^{2}\right)\end{array}$ \\
\hline $11-09-2009$ & 246 & 19 & BDL & BDL & 82 & 6 & 2.4 & 0.2 & 1,110 & 86 \\
\hline $12-07-2009$ & 183 & 14 & BDL & BDL & 42 & 3 & 2.6 & 0.2 & 897 & 69 \\
\hline 01-26-2010 & 215 & 17 & 26 & 2 & 36 & 3 & 1.7 & 0.1 & 897 & 69 \\
\hline 02-23-2010 & 398 & 31 & 9 & 1 & 76 & 6 & BDL & BDL & 1,149 & 89 \\
\hline 03-16-2010 & 1,146 & 88 & BDL & BDL & 196 & 15 & BDL & BDL & 3,497 & 270 \\
\hline $04-22-2010$ & 1,491 & 115 & 33 & 3 & 135 & 10 & BDL & BDL & 5,145 & 397 \\
\hline 05-14-2010 & 92 & 7 & 3 & 0.3 & 13 & 1 & BDL & BDL & 386 & 30 \\
\hline $05-25-2010$ & 59 & 5 & BDL & BDL & 5 & 0.4 & BDL & BDL & 247 & 19 \\
\hline 06-10-2010 & 19 & 1 & 1 & 0.1 & 3 & 0.2 & 0.2 & 0.0 & NA & NA \\
\hline 07-26-2010 & 714 & 55 & 31 & 2 & 204 & 16 & BDL & BDL & 2,956 & 228 \\
\hline 09-07-2010 & 576 & 44 & 50 & 4 & 146 & 11 & 3.4 & 0.3 & 2,959 & 229 \\
\hline $10-06-2010$ & 2,186 & 169 & 79 & 6 & 794 & 61 & 9.7 & 0.7 & 9,480 & 732 \\
\hline $11-16-2010$ & 629 & 49 & 21 & 2 & 99 & 8 & BDL & BDL & 3,058 & 236 \\
\hline 01-11-2011 & 126 & 10 & 11 & 1 & 30 & 2 & BDL & BDL & 642 & 50 \\
\hline 05-03-2011 & 1,433 & 111 & BDL & BDL & 460 & 36 & 7.9 & 0.6 & NA & NA \\
\hline 05-16-2011 & 726 & 56 & 38 & 3 & 179 & 14 & BDL & BDL & 1,695 & 131 \\
\hline 06-21-2011 & 66 & 5 & BDL & BDL & BDL & BDL & 0.9 & 0.1 & 274 & 21 \\
\hline 07-26-2011 & 3,227 & 249 & 41 & 3 & 821 & 63 & 19.7 & 1.5 & 11,989 & 926 \\
\hline 09-22-2011 & 9,315 & 719 & BDL & BDL & 1,673 & 129 & 28.9 & 2.2 & 28,883 & 2,230 \\
\hline $10-26-2011$ & E17,000 & $\mathrm{E} 1,300$ & E190 & E15 & $\mathrm{E} 6,400$ & E500 & E90 & E7.1 & E51,000 & $\mathrm{E} 4,000$ \\
\hline
\end{tabular}

Table 7. Instantaneous flux and specific flux for total mercury and methylmercury in the filtered and particulate phase, and dissolved organic carbon flux and specific flux for Salmon River, Glacier Bay National Park and Preserve, Alaska, November 9, 2009, to 0ctober 26, 2011.

[Abbreviations: FTHg, filtered total mercury; FMHg, filtered methylmercury; PTHg, particulate total mercury; PMHg, particulate methylmercury; sp flux, specific flux; ng/s, nanograms per second; (ng/s)/ $\mathrm{km}^{2}$, nanograms per second per square kilometer; BDL, below detection limit; NA, not available due to loss of sample or lack of collection; E, estimated]

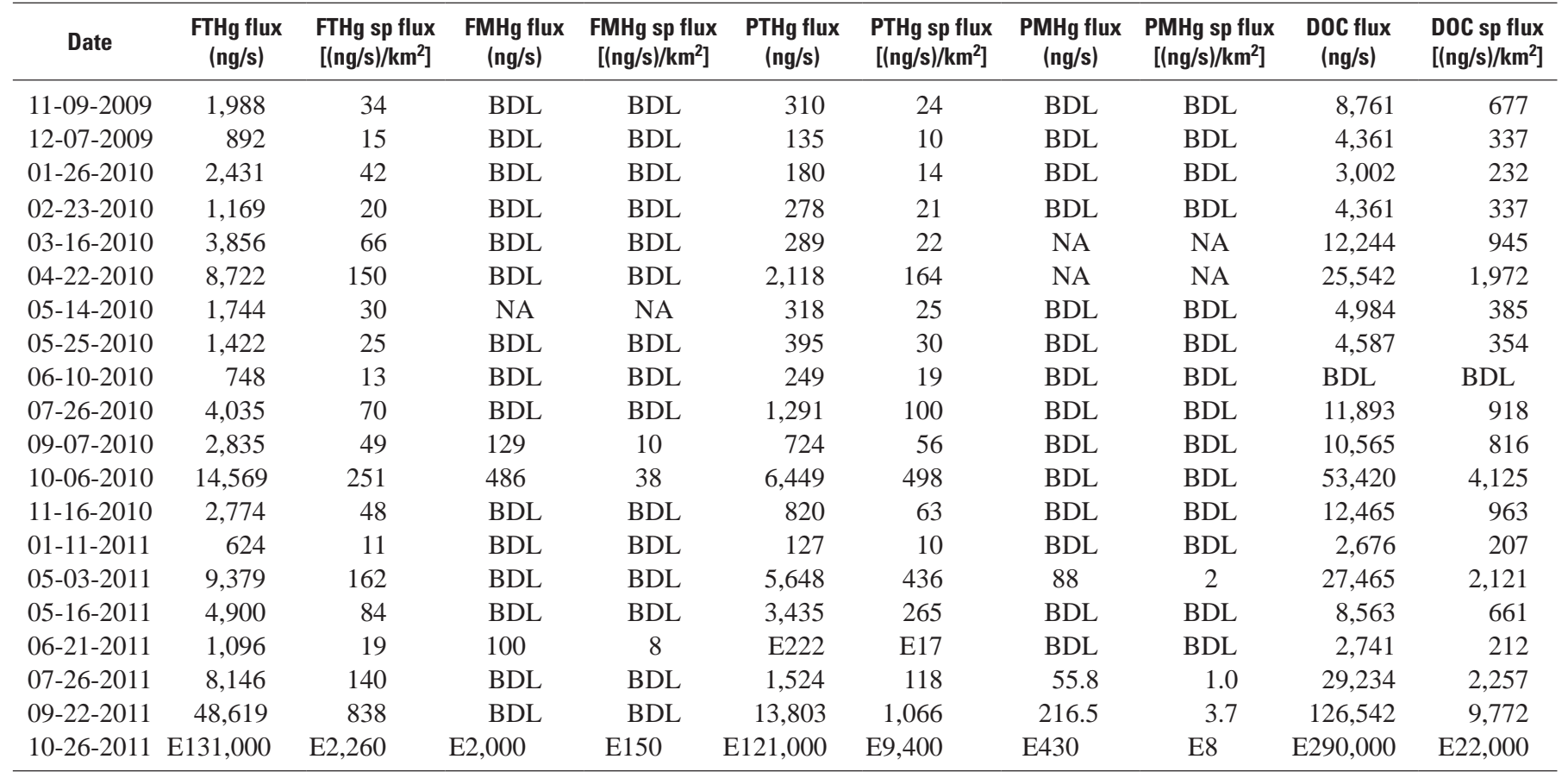


Table 8. Instantaneous flux and specific flux for total mercury and methylmercury in the filtered and particulate phase, and dissolved organic carbon flux and specific flux for Good River, Glacier Bay National Park and Preserve, Alaska, November 9, 2009, to 0ctober 26, 2011.

[Abbreviations FTHg, filtered total mercury; FMHg, filtered methylmercury; PTHg, particulate total mercury; PMHg, particulate methylmercury; sp flux, specific flux; ng/s, nanograms per second; (ng/s) $/ \mathrm{km}^{2}$, nanograms per second per square kilometer; BDL, below detection limit; NA, not available due to loss of sample or lack of collection; E, estimated]

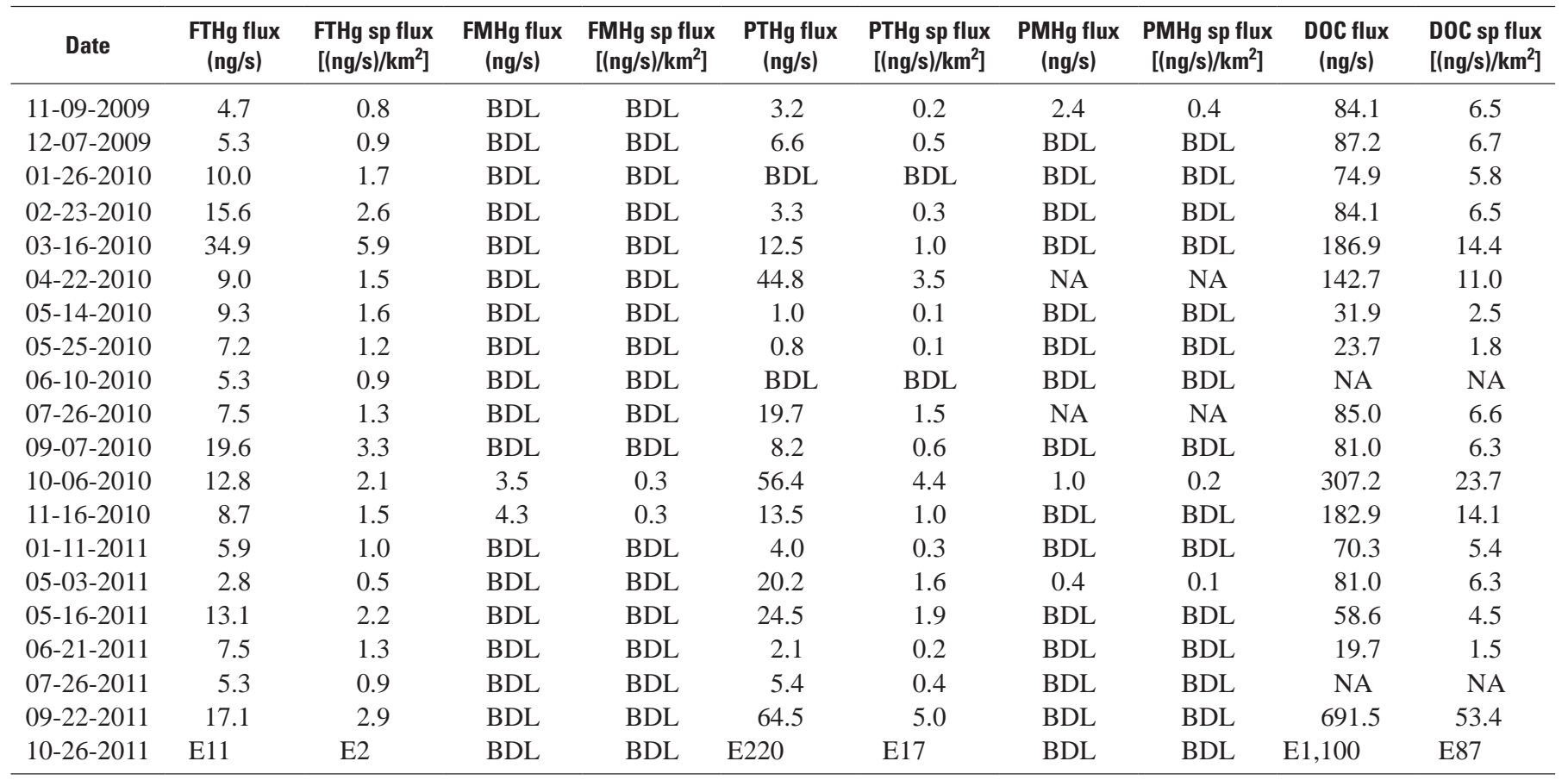

Table 9. Concentrations of total mercury in streambed sediments collected at Rink Creek, Salmon River, and Good River, Glacier Bay National Park and Preserve, Alaska, May 24, 2010.

[Abbreviation: ng/g, nanograms per gram, dry weight]

\begin{tabular}{cc}
\hline $\begin{array}{c}\text { Site } \\
\text { name }\end{array}$ & $\begin{array}{c}\text { Total mercury } \\
\text { (ng/g) }\end{array}$ \\
\hline Rink Creek & 35.5 \\
Salmon River & 19.6 \\
Good River & 9.9 \\
\hline
\end{tabular}


Table 10. Taxonomy, trophic position, and mercury concentrations in benthic macroinvertebrates from Rink Creek, Salmon River, and Good River, Glacier Bay National Park and Preserve, Alaska, 2010 and 2011.

[Trophic position: Sh, shredder; C-G, collector-gatherer; Sc, scraper; P, predator. MeHg percentage of total mercury as methylmercury. Abbreviations BMHg, biota methylmercury; BTHg, biota total mercury; ng/g, nanograms per gram; -, no data]

\begin{tabular}{|c|c|c|c|c|c|c|c|c|c|}
\hline $\begin{array}{c}\text { Sample } \\
\text { date }\end{array}$ & Group & Order & Family & Genus & Species & $\begin{array}{l}\text { Trophic } \\
\text { position }\end{array}$ & $\begin{array}{l}\text { BMHg } \\
\text { (ng/g) }\end{array}$ & $\begin{array}{l}\text { BTHg } \\
\text { (ng/g) }\end{array}$ & $\begin{array}{c}\text { MeHg } \\
\text { (percent) }\end{array}$ \\
\hline \multicolumn{10}{|c|}{ Rink Creek } \\
\hline 06-21-2011 & Caddisfly & Trichoptera & Limnephilidae & Onocosmoecus & - & Sh & 18.0 & 32.7 & 55 \\
\hline 06-21-2011 & Mayfly & Ephemeroptera & Ameletidae & Ameletus & - & C-G & 96.9 & 138 & 70 \\
\hline $05-25-2010$ & Mayfly & Ephemeroptera & Baetidae & Baetis & tricaudatus+bicaudatus & C-G & 52.7 & - & - \\
\hline 06-21-2011 & Mayfly & Ephemeroptera & Ephemerellidae & Drunella & grandis & Sc, $\mathrm{P}$ & 96.2 & 146 & 66 \\
\hline \multicolumn{10}{|c|}{ Salmon River } \\
\hline $05-25-2010$ & Caddisfly & Trichoptera & Limnephilidae & Onocosmoecus & - & Sh & 8.8 & - & - \\
\hline 06-21-2011 & Caddisfly & Trichoptera & Limnephilidae & Onocosmoecus & - & Sh & 14.9 & 49.7 & 30 \\
\hline 06-21-2011 & Mayfly & Ephemeroptera & Ephemerellidae & Drunella & grandis & Sc, P & 48.1 & 109 & 44 \\
\hline \multicolumn{10}{|c|}{ Good River } \\
\hline 05-25-2010 & Caddisfly & Trichoptera & Limnephilidae & Onocosmoecus & - & Sh & 5.9 & - & - \\
\hline 06-21-2011 & Caddisfly & Trichoptera & Limnephilidae & - & - & Sh & 11.2 & 23.2 & 48 \\
\hline 05-25-2010 & Mayfly & Ephemeroptera & Baetidae & Baetis & tricaudatus & $C-G$ & 9.3 & - & - \\
\hline
\end{tabular}

Table 11. Methylmercury and total mercury concentrations (wet weight and dry weight) in juvenile coho salmon samples from Rink Creek, Salmon River, and Good River, Glacier Bay National Park and Preserve, Alaska, 2010 and 2011.

[MeHg percent of total mercury as methylmercury. Abbreviations mm, millimeters; BMHg, biota methylmercury; BTHg, biota total mercury; std dev, standard deviation; ng/g dw, nanograms per gram dry weight; ng/g ww, nanograms per gram wet weight; NA, not analyzed; -, no data]

\begin{tabular}{cccccccc}
\hline $\begin{array}{c}\text { Site } \\
\text { name }\end{array}$ & $\begin{array}{c}\text { Sample } \\
\text { date }\end{array}$ & $\begin{array}{c}\text { Sample } \\
\text { size }\end{array}$ & $\begin{array}{c}\text { Fish length (mm) } \\
\text { mean (std dev) }\end{array}$ & $\begin{array}{c}\text { BMHg } \\
\text { (ng/g dw) }\end{array}$ & $\begin{array}{c}\text { BMHg } \\
\text { (ng/g ww) }\end{array}$ & $\begin{array}{c}\text { BTHg } \\
\text { (ng/g dw) }\end{array}$ & $\begin{array}{c}\text { BTHg } \\
\text { (ng/g ww) }\end{array}$ \\
\hline Rink Creek & $05-14-2010$ & 8 & $99(5)$ & $($ NA) & (NA) & 112 & 24.4 \\
& $05-17-2011$ & 10 & $64(8)$ & 236 & 51.4 & 281 & 61.2 \\
(percent)
\end{tabular}


Table 12. Concentrations of total dissolved solids, major anions, and major cations from water samples collected at Rink Creek, Salmon River, and Good River, Glacier Bay National Park and Preserve, Alaska, 2010.

[The number in parentheses (below each constituent) is used by U.S. Environmental Protection Agency and U.S. Geological Survey to identify parameters in computerized databases. Abbreviations mg/L, milligrams per liter; E, estimated; <, less than]

\begin{tabular}{|c|c|c|c|c|c|c|c|c|c|c|}
\hline Date & $\begin{array}{l}\text { Dissolved } \\
\text { solids } \\
\text { (mg/L) } \\
(70300)\end{array}$ & $\begin{array}{c}\text { Calcium } \\
\text { (mg/L) } \\
(00915)\end{array}$ & $\begin{array}{c}\text { Magnesium } \\
(\mathrm{mg} / \mathrm{L}) \\
(00925)\end{array}$ & $\begin{array}{c}\text { Potassium } \\
\text { (mg/L) } \\
(00935)\end{array}$ & $\begin{array}{c}\text { Sodium } \\
\text { (mg/L) } \\
(00930)\end{array}$ & $\begin{array}{c}\text { Alkalinity } \\
\text { (mg/L) } \\
(29801)\end{array}$ & $\begin{array}{c}\text { Chloride } \\
\text { (mg/L) } \\
(00940)\end{array}$ & $\begin{array}{c}\text { Flouride } \\
\text { (mg/L) } \\
(00950)\end{array}$ & $\begin{array}{c}\text { Silica } \\
\text { (mg/L) } \\
(00955)\end{array}$ & $\begin{array}{l}\text { Sulfate } \\
\text { (mg/L) } \\
\text { (00945) }\end{array}$ \\
\hline \multicolumn{11}{|c|}{ Rink Creek } \\
\hline 04-22-2010 & 55 & 11 & 0.838 & 0.32 & 2.56 & 31.8 & 3.54 & $<0.08$ & 2.45 & 0.75 \\
\hline 09-07-2010 & 104 & 21.9 & 1.72 & 0.7 & 4.76 & 60.8 & 7.25 & $<0.08$ & 4.44 & 1.03 \\
\hline \multicolumn{11}{|c|}{ Salmon River } \\
\hline 04-22-2010 & 88 & 23.1 & 1.99 & 0.56 & 3.75 & 64.5 & 5.37 & $<0.08$ & 2.65 & 4.02 \\
\hline 09-07-2010 & 149 & 35.9 & 3.93 & 1.21 & 10.3 & 101 & 16.4 & $<0.08$ & 4.44 & 5.52 \\
\hline $10-06-2010$ & 110 & 26.2 & 2.28 & 0.64 & 3.49 & 70.9 & 5.34 & $<0.04$ & 3.14 & 4.61 \\
\hline 09-07-2010 & 198 & 65.5 & 4.34 & 1.94 & 3.42 & 186 & 2.79 & $<0.08$ & 10.6 & 0.38 \\
\hline $10-06-2010$ & 173 & 51.6 & 2.42 & 1.52 & 1.97 & 148 & 2.69 & $<0.04$ & 7.18 & 0.38 \\
\hline $11-16-2010$ & 162 & 57 & 3.15 & 1.52 & 2.41 & 159 & 2.2 & 0.05 & 8.52 & 0.42 \\
\hline
\end{tabular}

Table 13. Concentrations of ammonia, nitrogen and phosphorus species, dissolved iron, and dissolved manganese from water samples collected at Rink Creek, Salmon River, and Good River, Glacier Bay National Park and Preserve, Alaska, 2010.

[The number in parentheses (below each constituent) is used by U.S. Environmental Protection Agency and U.S. Geological Survey to identify parameters in computerized databases. Abbreviations N, nitrogen; P, phosphorus; mg/L, milligrams per liter; $\mu \mathrm{g} / \mathrm{L}$, micrograms per liter; E, estimated; <, less than; - , no data]

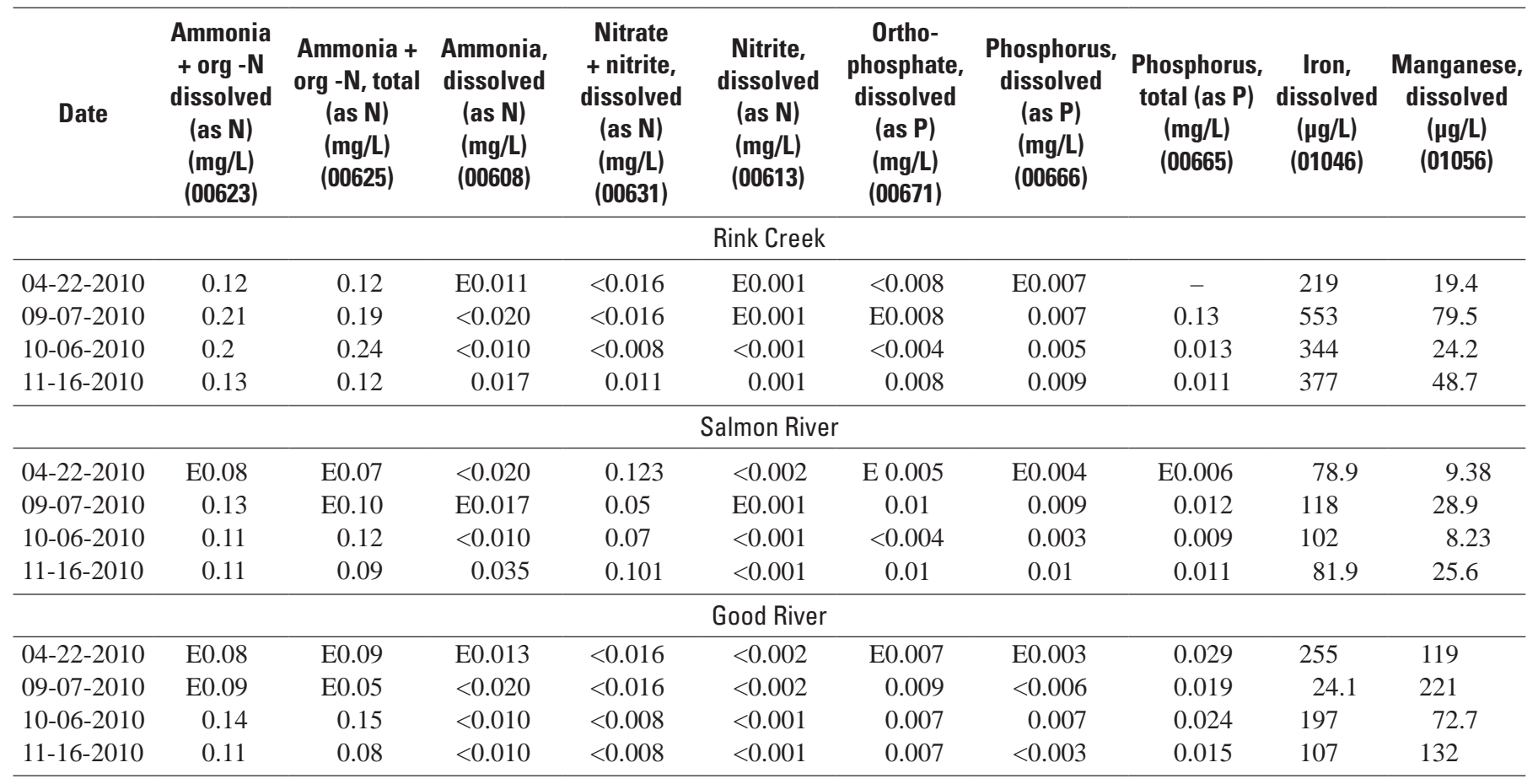




\section{Acknowledgments}

The authors wish to thank the following people for their efforts in this project. John Hudson (independent aquatic ecologist) assisted in the collection and identification of the benthic macroinvertebrates. Kenna Butler of the USGS National Research Program processed the DOC, UVA, and SUVA samples. John DeWild of the USGS Mercury Research Laboratory processed all mercury samples. Chad Soiseth of Glacier Bay National Park and Preserve arranged logistics for sampling crews traveling to Gustavus and collected samples during the high-flow event on October 26, 2011.

\section{References Cited}

Aiken, G.R., 1992, Chlorine interference in the analysis of dissolved organic carbon by the wet oxidation method: Environmental Science and Technology, v. 26, no. 12, p. 2,435-2,439.

Alaska Department of Fish and Game, 2005, Catalog of waters important for spawning, rearing or migration of anadromous fishes: Juneau, Alaska Department of Fish and Game, 205 p.

Bradsher, Keith, and Barboza, David, 2006, Pollution from Chinese coal casts a global shadow: New York, New York Times article, June 16, 2006.

Brew, D.A., 2008, Delineation of landform and lithologic units for ecological landtype-association analysis in Glacier Bay National Park, southeast Alaska: U.S. Geological Survey Scientific Investigations Report 2008-5183, 7 p. (Also available at http://pubs.usgs.gov/sir/2008/5183/.)

Connor, C.L., Streveler, G.P., Post, A., Monteith, D., and Howell, W., 2009, The neoglacial landscape and human history of Glacier Bay, Glacier Bay National Park and Preserve, southeast Alaska, USA: The Holocene, v. 19, no. 3, p. 381-393.

Dastoor, A.P., and Larocque, Y., 2004, Global circulation of atmospheric mercury-A modelling study: Atmospheric Environment, v. 38, p. 147-161.

Day, R.D., Vander Pol, S.S., Christopher, S.J., Davis, W.C., Pugh, R.S., Simac, K., Roseneau, D.G., and Becker, P.R., 2006, Murre eggs (Uria aalge and Uria Iomvia) as indicators of mercury contamination in the Alaskan marine environment: Environmental Science and Technology, v. 40, no. 3, p. 659-665.

DeWild, J.F., Olson, M.L., and Olund, S.D., 2001, Determination of methyl mercury by aqueous phase ethylation, followed by gas chromatographic separation with cold vapor atomic fluorescence detection: U.S. Geological Survey Open-File Report 2001-445, 14 p. (Also available at http://pubs.usgs.gov/of/2001/ofr-01-445/.)
DeWild, J.F., Olund, S.D., Olson, M.L., and Tate, M.T., 2004, Methods for the preparation and analysis of solids and suspended solids for methylmercury: U.S. Geological Survey Techniques and Methods, book 5, chap. A7, 13 p. (Also available at http://pubs.usgs.gov/tm/2005/tm5A7/.)

Engstrom, D.R., and Swain, E.B., 1997, Recent declines in atmospheric mercury deposition in the upper midwest: Environmental Science and Technology, v. 31, p. 960-967.

Fellman, J.B., D’Amore, D.V., Hood, Eran, and Boone, R.D., 2007, Fluorescence characteristics and biodegradability of dissolved organic matter in forest and wetland soils from coastal temperate watersheds in southeast Alaska: Biogeochemistry, v. 88, no. 2, p. 169-184, DOI 10.1007/ s10533-008-9203-x.

Fishman, M.J., and Friedman, L.C., eds., 1989, Methods for determination of inorganic substances in water and fluvial sediments (3d. ed.), U.S. Geological Survey Techniques of Water-Resources Investigations, book 5, chap. A1, p. 545. (Also available at http://pubs.usgs.gov/twri/twri5-a1/.)

Fitzgerald, W.F., Engstrom, D.R., Lamborg, C.H., Tseng, C.M., Balcom, P.H., and Hammerschmidt, C.R., 2005, Modern and historic atmospheric mercury fluxes in northern Alaska-Global source and arctic depletion: Environmental Science and Technology, v. 39, p. 557-568.

Fitzgerald, W.F., Engstrom, D.R., Mason, R.P., and Nater, E.A., 1998, The case for atmospheric mercury contamination in remote areas: Environmental Science and Technology v. 32, p. 1-7.

Hammerschmidt, C.R., and Fitzgerald, W.F., 2006, Bioaccumulation and trophic transfer of methylmercury in Long Island Sound: Archives of Environmental Contamination and Toxicology, v. 51, p. 416-424.

Horvat, M., and Bloom, N.S., 1993, Comparison of distillation with other current isolation methods for the determination of methyl mercury compounds in low level environmental samples-Part 1, Sediments: Analytica Chimica Acta, v. 281, no. 1, p. 135-152.

Krabbenhoft, D.P., Wiener, J.G., Brumbaugh, W.G., Olson, M.L., DeWild, J.F., and Sabin, T.J., 1999, A national pilot study of mercury contamination of aquatic ecosystems along multiple gradients: U.S. Geological Survey Biological Science Report 2001-0009, 25 p.

Nagorski, S.A., Engstrom, D.E., Hudson, John, Krabbenhoft, D.P., DeWild, J.F., Hood, Eran, and Aiken, G.R., 2011, Scale and distribution of global pollutants in Southeast Alaska Network park watersheds: Natural Resource Technical Report NPS/SEAN/NRTR—2011/496, 67 p., accessed March 6, 2013, at http://science.nature.nps.gov/ im/units/sean/auxrep/FC/FC Nagorski\%20NRTR\%202011496.pdf. 
National Atmospheric Deposition Program, 2012, Mercury Deposition Network: National Atmospheric Deposition Program web site, accessed November 14, 2012, at http:// nadp.sws.uiuc.edu/mdn/.

National Oceanic Atmospheric Association, variously dated, National Weather Service Climate station Gustavus, Alaska, accessed August 15, 2012 at http://www.wrcc.dri.edu/ summary/Climsmak.html.

Nriagu, J.G., and Pacyna, J.M., 1988, Quantitative assessment of worldwide contamination of air, water, and soils with trace metals: Nature, v. 333, p. 134-139.

Olund, S.D., DeWild, J.F., Olson, M.L., and Tate, M.T., 2004, Methods for the preparation and analysis of solids and suspended solids for total mercury: U.S. Geological Survey Techniques and Methods book 5, chap. A8, 15 p. (Also available at http://pubs.usgs.gov/tm/2005/tm5A8/.)

Pacyna, E.G., Pacyna, J.M., Sundseth, K., Munthe, J., Kindbom, K., Wilson, S., Steenhuisen, F., and Maxon, P., 2010, Global emission of mercury to the atmosphere from anthropogenic sources in 2005 and projections to 2020: Atmospheric Environment, v. 44, p. 2487-2499.

Rossman, D.L., 1963, Geology of the eastern part of the Mount Fairweather quadrangle, Glacier Bay, Alaska: U.S. Geological Survey Bulletin, v. 1121-K, p. 1-57.

Schroeder, W.H., and Munthe, J., 1998, Atmospheric mercury-An overview: Atmospheric Environment, v. 32, p. 809-822.

Streveler, G.P., 1996, The natural history of Gustavus: G. Streveler, 53 p.

Sunderland, E.M., Krabbenhoft, D.P., Moreau, J.W., Strode, S.A., and Landing, W.M., 2009, Mercury sources, distribution, and bioavailability in the North Pacific Ocean-Insights from data and models: Global Biogeochemical Cycles, v. 23, no. GB2010, 14 p., doi:10.1029/2008GB003425.
Turnipseed, D.P., and Sauer, V.B., 2010, Discharge measurements at gaging stations: U.S. Geological Survey Techniques and Methods, book 3, chap. A8, 87 p. (Also available at http://pubs.usgs.gov/tm/tm3-a8/.)

U.S. Energy Information Administration, 2012, U.S. Energy Information Administration International Energy Statistics through 2010: U.S. Energy Information Administration web site, accessed October 26, 2012, at http://www.eia.gov/ cfapps/ipdbproject/iedindex3.cfm?tid=1\&pid=1\&aid=2\&ci $\underline{\mathrm{d}=\text { =regions\&syid=1980\&eyid=2010\&unit=TST. }}$.

U.S. Environmental Protection Agancy, 2002, Method 1631-Mercury in water by oxidation, purge and trap, and cold vapor atomic fluorescence spectrometry: U.S. Environmental Protection Agency, Revision E, EPA 821-R95-027.

U.S. Fish and Wildlife Service, variously dated, National Wetlands Inventory, accessed September 10, 2012, at http:// www.fws.gov/wetlands/Data/State-Downloads.html.

U.S. Geological Survey, variously dated, National field manual for the collection of water-quality data: U.S. Geological Survey Techniques of Water-Resources Investigations, book 9, chaps. A1-A9. (Also available at http://water.usgs. gov/owq/FieldManual/.)

Weishaar, J.L., Aiken, G.R., Bergamaschi, B.A., Fram, M.S., Fuji, R., and Mopper, K., 2003, Evaluation of specific ultraviolet absorbance as an indicator of the chemical composition and reactivity of dissolved organic carbon: Environmental Science and Technology, v. 37, p. $4,702-4,708$.

Wiener, J.G., Krabbenhoft, D.P., Heinz, G.H., and Scheuhammer, A.M., 2003, Ecotoxicology of mercury, in Hoffman, D.J., Rattner, B.A., and Burton, G.A.J., eds., Handbook of Ecotoxicology: CRC Press, p. 1290. 
Publishing support provided by the U.S. Geological Survey Publishing Network, Tacoma Publishing Service Center

For more information concerning the research in this report, contact the Director, Alaska Science Center

U.S. Geological Survey

4210 University Dr.

Anchorage, Alaska 99508-4560

http://alaska.usgs.gov 


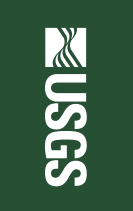

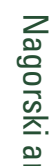

言

官

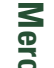

를

言

蛋

ํㅗㄹ

율

융

몽

ํㅗㄱ.

品

을.

꾹

ํㅡㄹ

Tั่

吝

ำ

ิㅗำ

ํํำ

름

응

!

옹

홈

올

$\overrightarrow{0}$

옹

高

ग

윽

옹

它 